\title{
All102461642
}

NATL INST OF STANDAROS \& TECH R.I.C.

\section{A Literature Review of the Chemical Nature and Toxicity of the Decomposition Products of Polyethylenes}

\section{Reference}

NBS

\section{PUBLICATIONS}

Maya Paabo

Barbara C. Levin

U.S. DEPARTMENT OF COMMERCE

National Bureau of Standards

National Engineering Laboratory

Center for Fire Research

Gaithersburg, MD 20899

January 1986

Sponsored in part by:

$-Q C \longrightarrow$ U.S. Consumer Product Safety Commission thesda, MD 20207 

$\because 0$
A LITERATURE REVIEW OF THE
CHEMICAL NATURE AND TOXICITY OF
THE DECOMPOSITION PRODUCTS OF POLYETHYLENES

\author{
Maya Paabo \\ Barbara C. Levin
}

U.S. DEPARTMENT OF COMMERCE

National Bureau of Standards

National Engineering Laboratory

Center for Fire Research

Gaithersburg, MD 20899

January 1986

Sponsored in part by:

The U.S. Consumer Product Safety Commission

Bethesda, MD 20207

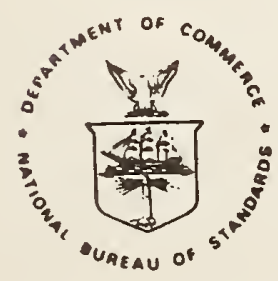

U.S. DEPARTMENT OF COMMERCE, Malcolm Baldrige, Secretary NATIONAL BUREAU OF STANDARDS. Ernest Ambler, Director 

TABLE OF CONTENTS

Page

List of Tables $\ldots \ldots \ldots \ldots \ldots \ldots \ldots \ldots \ldots \ldots \ldots \ldots \ldots \ldots \ldots \ldots \ldots \ldots \ldots \ldots \ldots \ldots \ldots$ iv

Abstract $\ldots \ldots \ldots \ldots \ldots \ldots \ldots \ldots \ldots \ldots \ldots \ldots \ldots \ldots \ldots \ldots \ldots \ldots \ldots \ldots \ldots \ldots \ldots \ldots \ldots \ldots$

1. INTRODUCTION $\ldots \ldots \ldots \ldots \ldots \ldots \ldots \ldots \ldots \ldots \ldots \ldots \ldots \ldots \ldots \ldots \ldots \ldots \ldots \ldots \ldots \ldots \ldots \ldots$

2. THERMAL DECOMPOSITION $\ldots \ldots \ldots \ldots \ldots \ldots \ldots \ldots \ldots \ldots \ldots \ldots \ldots \ldots \ldots \ldots \ldots \ldots \ldots \ldots \ldots$

2.1 Thermal Degradation in the Absence of 0xygen .............. 5

2.1 .1 Vacuum Pyrolysis .............................. 5

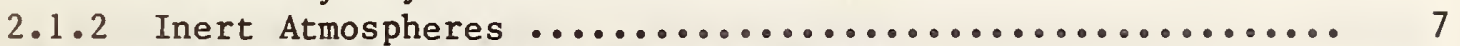

2.2 Smal1-Scale Tests in Oxidative Atmospheres ................ 9

2.2.1 Generation of $\mathrm{CO}$ and $\mathrm{CO}_{2} \ldots \ldots \ldots \ldots \ldots \ldots \ldots \ldots \ldots \ldots \ldots \ldots \ldots \ldots$

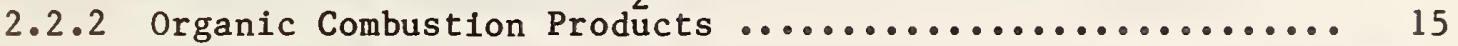

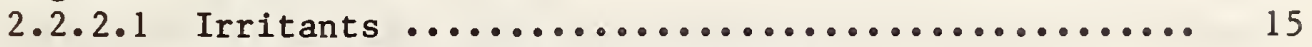

2.2.2.2 Non-Irritant Organic Compounds ............. 17

2.2.2.3 Polycyclic Aromatic Hydrocarbons ............. 21

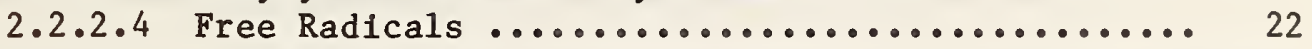

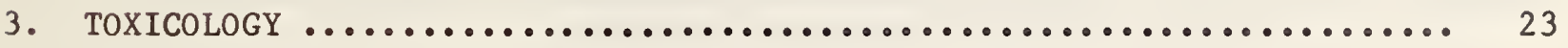

3.1 DIN Toxicity Test Method ............................. 24

3.2 University of San Francisco (USF) Toxicity Test Method ........ 29

3.3 Federal Aviation Administration (FAA/CAMI) Toxicity

Test Method ...................................... 31

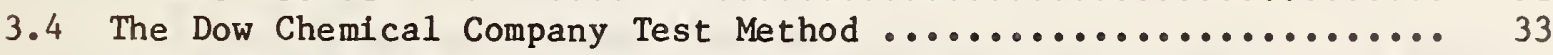

3.5 Large-Scale Tests ................................. 36

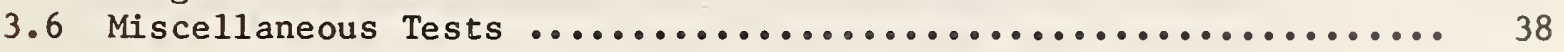

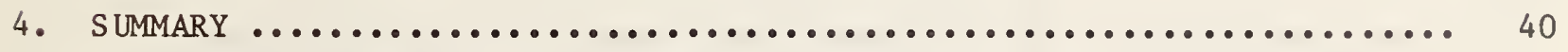

5. ACKNOWLEDGMENTS ...................................... 42

6. REFERENCES ........................................... 42 
Table 1. Therma1 Degradation Products Produced from Polyethylenes ..... 48

Table 2. Degradation Products Generated from Polyethylene During Pyrolysis, Thermooxidation, and Combustion ................ 52

Table 3. $\mathrm{CO}$ and $\mathrm{CO}_{2}$ Concentrations in the Combustion Products from a Polyethylene ............................... 54

Table 4. Concentrations of Polycyclic Aromatic Hydrocarbons in Smoke Particulates from Polyethylene .................. 55

Table 5. Toxicological Effects on Rats Exposed to the Pyrolysis Products from a Polyethylene Decomposed by the DIN

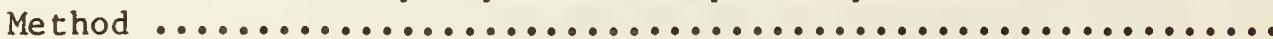

Table 6. Toxicological Effects on Rats Exposed to Combustion Products from Polyethylene Decomposed According to the

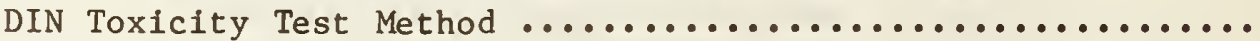

Table 7. Variation of Mean Respiration Frequency in Rats Exposed to Polyethylene Decomposition Products ...................

Table 8. Toxicity Results for Polyethylene Decomposed According to the UnIversity of San Francisco Method Using the Rising

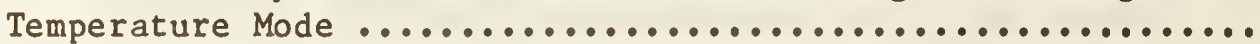

Table 9. Survival Times of Test Animals Exposed to Smoke from Polyethylene Decomposed under Different University of San Francisco Test Method Conditions ......................

Table 10. Gas Analyses of the Combustion Products from Polyethylene Examined via the University of San Francisco Test Method .....

Table 11. LC 50 Values Calculated for Different Polyethylene Foams Decomposed by the Dow Chemical Company Test Procedures .......

Table 12. Influence of Heating Rates on the Toxicity of Combustion Products from Polyethylene ........................... 
A LITERATURE REVIEW OF THE CHEMICAL NATURE AND TOXICITY OF THE DECOMPOSITION PRODUCTS OF POLYETHYLENES

Maya Paabo and Barbara C. Levin

Abstract

The literature on polyethylenes has been reviewed with an emphasis on the identification of gaseous products generated under various thermal decomposition conditions and the toxicity of those products. This review is limited to publications in English through 1984. The analytical chemical studies of the thermal decomposition products generated under vacuum, inert and oxidative experimental conditions are described. In oxidative atmospheres, which most closely simulate real fire conditions, carbon monoxide ( $\mathrm{CO}$ ) was found to be the predominant toxicant. Acrolein was another toxicant often noted in these reviewed studies. More acrolein was generated under non-flaming than under flaming conditions.

Results from seven different test procedures were considered in assessing the acute inhalation toxicity of combustion products from various polyethylene formulations. The combustion products generated from the polyethylenes studied in the non-flaming mode appeared to be slightly more toxic than those produced in the flaming mode. In the non-flaming mode, the $\mathrm{LC}_{50}$ values ranged from 5 to $75 \mathrm{mg} / \mathrm{l}$. In the flaming mode, the $L_{50}$ values ranged from 31 to $51 \mathrm{mg} / \mathrm{l}$. The toxicity of the degradation products of polyethylenes appears to be similar to that found for other common materials designed for the same end uses.

Keywords: combustion products, literature reviews, polyethylenes, thermal decomposition, toxicity. 


\section{INTRODUCTION}

Polyethylene has been in commercial production for over forty years. With sales of about $6.25 \times 10^{6}$ metric tons in 1983, polyethylenes compose the largest fraction of plastic materials produced [1] $]^{1}$. Typical uses of polyethylenes include household goods (bottles, dishes and toys), packaging materials, and coatings for tubing and cables in the building and electrical industries. This report reviews the literature on polyethylene published in English through 1984 with special emphasis on the gaseous products generated under varfous thermal decomposition conditions and the toxicity of those products.

Polyethylenes are thermoplastic materials that are produced primarily by the catalytic polymerization of ethylene gas $\left(\mathrm{C}_{2} \mathrm{H}_{4}\right)$ at elevated temperatures $(\mathrm{T})$ and pressures (P).

$$
\begin{array}{ll}
\mathrm{n}\left(\mathrm{CH}_{2}=\mathrm{CH}_{2}\right) \frac{\text { catalyst }}{\mathrm{T}, \mathrm{P}} & \underset{2}{\mathrm{CH}_{2}}-\mathrm{CH}_{2} \mathrm{CH}_{\mathrm{n}} \\
\text { ethylene } & \text { polyethylene }
\end{array}
$$

The polyethylene molecules usually contain branches of various lengths. Of all the hydrocarbon polymers, polyethylene has the simplest structure and the highest ratio of hydrogen to carbon in 1ts backbone. Most commercial polyethylene formulations also contain additives, such as stabilizers, antioxidants, crosslinking agents, slip and antiblock agents, and fire retardants.

\footnotetext{
${ }^{1}$ Numbers in brackets refer to the 11terature reference 11 sted at the end of this report.
} 
The molecular structure, molecular weight distribution, and density will differ in various polyethylenes depending on the manufacturing process conditions. Low density polyethylene (LDPE) is of low crystallinity $(<60 \%)$ and has a density in the range of $0.91-0.94 \mathrm{~g} / \mathrm{cm}^{3}$ and a molecular weight of about $4 \times 10^{5} \mathrm{~g} / \mathrm{mol}$. High density polyethylene (HDPE) is of high crystallinity $(\sim 90 \%)$ and has a density in the range of $0.94-0.95 \mathrm{~g} / \mathrm{cm}^{3}$ and a molecular weight up to about $3 \times 10^{6} \mathrm{~g} / \mathrm{mol}$. LDPE molecules are highly branched in structure and may contain up to 30 branches with as many as 10 carbon atoms each. HDPE molecules are almost linear in structure with only few short branches. HDPE is more thermostable than LDPE since secondary carbon-hydrogen bonds are stronger than tertiary carbon-hydrogen bonds $[2,3]$.

\section{THERMAL DECOMPOSITION}

The combustion of polyethylenes can produce many gaseous products, the nature of which depends mainly on the external conditions such as temperature and oxygen availability. The final products formed during complete combustion of polyethylenes are carbon dioxide $\left(\mathrm{CO}_{2}\right)$ and water $\left(\mathrm{H}_{2} \mathrm{O}\right)$. Under incomplete flaming or non-flaming combustion conditions, many other low-molecular weight hydrocarbons and oxygenated compounds (e.g., carbon monoxide (CO), alcohols, aldehydes, ketones, and esters) are also generated. The combustion products that have been identified in the literature reviewed for this report are presented in Table 1 .

As all the C-C bonds in polyethylenes are of the same strength (except those in the terminal positions or at the sites where branching occurs), polyethylenes decompose mostly by a random-chain scission type mechanism Involving 
free-radical $\left(R^{\circ}\right)$ reactions. The suggested decomposition mechanisms include free radical formation by breakdown (eq. 2), free radical transfer within (eq. 3 ) or between molecules (eq. 4) with subsequent decompositions, and free radical termination by disproportionation (eq. 5) or by combination (eq. 6) $[4-6]$

$$
\begin{aligned}
& R-R \rightarrow 2 R^{\circ} \\
& \begin{aligned}
2 \mathrm{R}^{\bullet} \rightarrow \mathrm{R}-\dot{\mathrm{CH}}- & {\stackrel{\mathrm{CH}}{2}-\mathrm{CH}_{2}-\mathrm{R}} \\
& +\mathrm{R}^{\bullet}+\mathrm{CH}_{2}=\mathrm{CH}-\mathrm{CH}_{2}-\mathrm{R}
\end{aligned} \\
& \begin{aligned}
\mathrm{R}^{\bullet}+\mathrm{R}-\mathrm{CH}_{2}-\mathrm{R} \rightarrow \mathrm{R}-\dot{\mathrm{C}} \mathrm{H}-\mathrm{R}+\mathrm{RH} \\
\longrightarrow \mathrm{R}-\mathrm{CH}=\mathrm{CH}_{2}+\mathrm{R}^{\bullet}
\end{aligned} \\
& \dot{\mathrm{R}}+\dot{\mathrm{R}} \rightarrow \mathrm{R}-\mathrm{CH}=\mathrm{CH}_{2}+\mathrm{RH} \\
& \dot{R}+\dot{R} \rightarrow R-R
\end{aligned}
$$

Under oxidative conditions, additional reactions may occur. Oxygenated free radicals are involved in these reactions as for example:

$$
\begin{aligned}
& \mathrm{R}^{\circ} \mathrm{O}+\mathrm{H}_{3} \mathrm{C}-\mathrm{R} \rightarrow \mathrm{R}-\mathrm{CH}_{2} \mathrm{OH}+\mathrm{R}^{\bullet} \\
& \mathrm{ROO}+\mathrm{R}-\mathrm{CH}_{2} \mathrm{OH}+\mathrm{RCOOH}+\mathrm{R}-\dot{\mathrm{C}} \mathrm{HOH} \\
& \mathrm{R}^{\circ} \mathrm{O}+\mathrm{R}^{\circ} \rightarrow \mathrm{R}-\mathrm{O}-\mathrm{R}
\end{aligned}
$$


Fundamental studies of polyethylene degradation under various conditions have been reviewed by Madorsky [4], Schwartz [7] and Cullis and Hirschler [3].

\subsection{Thermal Degradation in the Absence of Oxygen}

When polyethylenes are exposed to elevated temperatures under inert atmospheric conditions, saturated and unsaturated hydrocarbons of various chain lengths are generated. Since polyethylenes do not contain any oxygen in their molecular structure, no $\mathrm{CO}, \mathrm{CO}_{2}$ or oxygen-containing organic compounds are produced. The composition of the volatile compounds which are formed from polyethylene products will reflect the presence of any additives present in the formulation.

\subsubsection{Vacuum Pyrolysis}

Identification of the volatile compounds generated from polyethylenes thermally decomposed under vacuum has been used in determining these degradation mechanisms. For example, a systematic mass spectrometric (MS) investigation by Madorsky et al. [4] found that a polyethylene (m.w. 20,000) pyrolyzed in vacuum at temperatures up to $450^{\circ} \mathrm{C}$ yielded 15 alkane and alkene type compounds, each containing 2-7 carbon atoms (Table 1). Only a small portion ( 4.3 mole \%) of the fraction volatile at $-80^{\circ} \mathrm{C}$ appeared as the monomer, indicating the absence of a zip mechanism, in which the polymer degrades into a monomer one unit at a time. Increasing the temperature increased the percentage of the monomer found in the degradation products. In particular, when a high-molecular-weight grade unbranched polyethylene (polymethylene) was pyrolyzed at $500^{\circ} \mathrm{C}, 800^{\circ} \mathrm{C}$ and $1200^{\circ} \mathrm{C}$, the weight percent of the monomer, 
ethylene, in the total volatiles increased from $0 \%$ to $5.5 \%$ and to $26.4 \%$, respectively. Based on the amount of ethylene formed, Madorsky proposed that two competing reactions occur when polyethylene decomposes. Below $800^{\circ} \mathrm{C}$ the thermal degradation proceeds by a fragmentation process. At higher temperatures, degradation proceeds by formation of free radicals which unzip producing the ethylene monomer.

Tsuchiya and Sumi also proposed that the main volatile degradation products from a polyethylene were formed by a mechanism involving the intramolecular migration of free radicals [5]. When samples of a commercially available HDPE were decomposed at fixed temperatures ranging from $375^{\circ} \mathrm{C}$ to $425^{\circ} \mathrm{C}$, twenty-six compounds consisting mainly of normal alkanes and normal 1-alkenes containing 1 to 6 carbon atoms were identified by gas chromatography (GC) (Table 1). As expected from eq. 3, the concentrations of these two classes of compounds were similar. The concentrations of ethylene and other hydrocarbons increased with increasing temperature. At $425^{\circ} \mathrm{C}$, the monomer yield was 11 mole percent in the fraction which was volatile at room temperature. These results agree reasonably with those of Madorsky [4] and other degradation studies cited by Tsuchiya and Sumi [5]. Free radical transfer involving local coiling was considered responsible for the relatively large amounts of propane and 1-hexene found in the degradation products. The predominant decomposition product, propylene, as well as isobutylene and 2-butene were all considered produced by a cleavage of the relatively weak $\mathrm{C}-\mathrm{C}$ bond in the $\beta$-position to the terminal double bond. 


\subsubsection{Inert Atmospheres}

The thermal degradation products of polyethylenes decomposed in inert atmospheres are very similar to those generated under vacuum conditions. In a study using infrared spectrometry (IR) to characterize the pyrolysis and combustion products of various polymers, Morimoto detected methane, ethylene, acetylene and benzene when a commercially available polyethylene was decomposed at $700^{\circ} \mathrm{C}$ in a nitrogen atmosphere [8].

Michal et al. studied the decomposition products of polyethylenes under three different conditions: pyrolysis in inert atmospheres, thermo-oxidation, and combustion in air [6]. When the pyrolysis products generated from a sample of a commercial polyethylene heated at $400^{\circ} \mathrm{C}$ under a flow of helium were analyzed by gas chromatography/mass spectrometry (GC/MS), forty-four different hydrocarbons were identified (Table 2). These compounds contained 3 to 18 carbon atoms and consisted mainly of alkanes and 1-alkenes. In addition, three aromatic compounds, benzene, toluene and ethyl benzene, were also detected.

A similar detailed study of the volatile products of an industrial high pressure type polyethylene decomposed at $510^{\circ} \mathrm{C}$ in an inert atmosphere was conducted by Pacakova et al. using pyrolysis gas chromatography [9]. The forty-eight compounds identified were mainly unsaturated hydrocarbons, consisting of 1-alkenes containing 5 to 9 carbons, corresponding n-alkanes and 1,3-alkadienes (Table 1). 
The composition of the thermal degradation products of polyethylenes was demonstrated to be partlally dependent on the molecular structure of the starting material by Hoff et al. [10]. They examined two samples of commerc1al polyethylenes: an LDPE without any additives and a HDPE containing an antioxidant and carbon black. The materials were decomposed in a Pyrex tube with a movable furnace at $360^{\circ} \mathrm{C}$ under a hellum atmosphere, and the gases were analyzed by GC and GC/MS techniques. Among the 25 products identified, the $\mathrm{C}_{4}$ hydrocarbons were dominant in both cases (Table 1). During the initial stages of thermal degradation, the degree of formation of $C_{2}$ to $C_{7}$ linear hydrocarbons was about the same for both samples. However, in final products, short-chain branched hydrocarbons were relatively more abundant in the combustion products generated from the LDPE sample than from the HDPE sample, which formed mostly linear hydrocarbons.

In addition to the usual decomposition products observed, polycyclic aromatic hydrocarbons (PAHs) have also been detected among the degradation products of polyethylenes [11]. Morikawa pyrolyzed a commercial grade of polyethylene in a quartz furnace under a nitrogen atmosphere. Benzo(a)pyrene $(\mathrm{BaP})$, which was used as an indicator for PAHs, was determined by high pressure liquid chromatography (HPLC). Evolution of BaP was found to increase at $900^{\circ} \mathrm{C}$ and higher temperatures. At $1000^{\circ} \mathrm{C}, \mathrm{BaP}$ was detected at a concentration of $1 \mathrm{mg} / \mathrm{g}$ of polyethylene; this amount is equivalent to that detected in an air-flowing atmosphere (see Section 2.2.2.3).

Since pure polyethylenes contain no oxygen, no oxygen-containing compounds would be expected to be generated during their pyrolysis in inert atmospheres. However, $\mathrm{CO}$ and $\mathrm{CO}_{2}$ have been detected in some studies $[6,8]$. 
(Michal, who specifically set out to measure the CO produced during the pyrolysis and thermooxidation of polymeric materials, detected no $\mathrm{CO}$ when a high-pressure type polyethylene was decomposed in helium at $500^{\circ} \mathrm{C} \mathrm{[12].)} \mathrm{The}$ $\mathrm{CO}$ and $\mathrm{CO}_{2}$ reported by others must have originated from additives, air trapped in the polyethylene formulation, or the inadvertent introduction of air or water vapor into the inert experimental environment. The production of $\mathrm{CO}$ can occur by the following reactions:

$$
\begin{aligned}
& \mathrm{C}+\mathrm{H}_{2} \mathrm{O}+\mathrm{CO}+\mathrm{H}_{2} \\
& \mathrm{C}_{n} \mathrm{H}_{2 n+2}+\mathrm{m}^{\prime} \mathrm{H}_{2} \mathrm{O}+\mathrm{C}_{\mathrm{m}} \mathrm{H}_{2 \mathrm{~m}+2}+\mathrm{m}^{\prime} \mathrm{CO}+2 \mathrm{~m}^{\prime} \mathrm{H}_{2}
\end{aligned}
$$

where $m+m^{\prime}=n$.

Morikawa examined this last possibility and found that when a polyethylene was decomposed in nitrogen, the evolution of $\mathrm{CO}$ due to the presence of added water vapor was small [13]. At $1000^{\circ} \mathrm{C}$, the amount of $\mathrm{CO}$ generated from a $500 \mathrm{mg}$ sample of polyethylene was about $0.05 \mathrm{~g} / \mathrm{g}$, which was an order of magnitude less than that found for materials containing oxygen in their structure. No Co generation was observed below $900^{\circ} \mathrm{C}$.

\subsection{Smal1-Scale Tests in Oxidative Atmospheres}

In order to evaluate the toxic atmospheres produced by polyethylenes decomposed in real fire situations, the thermal degradation of polyethylenes has been studied under a wide range of oxidative conditions and temperatures. Although large-scale tests can more closely simulate actual fire conditions, 
almost all the experiments included in this review have been conducted as smal1-scale laboratory tests. Non-flaming conditions, when used in smal1scale tests, are considered to represent an early fire stage when a material may be pyrolyzed some distance away from the combustion zone without being 1gnited.

In both flaming and non-flaming tests performed under oxidative conditions, a complex mixture of oxygen-containing organic compounds is formed in addition to the saturated and unsaturated hydrocarbons that were noted above to be generated in the absence of oxygen. $\mathrm{CO}$ and $\mathrm{CO}_{2}$ are the principal decomposition products generated. Certain oxygen-containing organic compounds, such as acrolein, formaldehyde and volatile carboxylic actds (formic acid, acetic acid and propionic acid), are also detected and may be of toxicological importance, since these compounds are considered to be irritants.

\subsubsection{Generation of $\mathrm{CO}$ and $\mathrm{CO}_{2}$}

Concentrations of $\mathrm{CO}$ and $\mathrm{CO}_{2}$ have been measured in most of the combustion studies of polyethylenes. The results of these studies have shown that the evolution of $\mathrm{CO}$ and $\mathrm{CO}_{2}$ is dependent on the air supply rate, the temperature of decomposition, and residence time of fuel vapor in the combustion zone.

In order to simulate different real-fire conditions, Michal $[12,14,15]$ used different combustion systems for pyrolysis in helium, oxidative nonflaming and flaming tests. During combustion in air with depleted oxygen content, the $\mathrm{CO}$ content in the thermal degradation products of a commercial 
polyethylene increased with increasing temperature. Under ventilated conditions, greater amounts of $\mathrm{CO}$ were detected in the non-flaming mode than in the flaming mode. When the $\mathrm{O}_{2}$ supply was limited, the concentration of $\mathrm{CO}$ was greater in the flaming mode than in the non-flaming mode. As expected, the $\mathrm{CO}_{2}$ content was found to be greatest during well-ventilated flaming combustion and was not temperature dependent.

In one study, Michal decomposed a high-pressure type polyethylene (Bralen $\mathrm{RB}$ 03-23) in a quartz combustion tube at $550^{\circ} \mathrm{C}$ in various gas mixtures of helium and oxygen [12]. Gas chromatography was used for determination of CO in the thermal degradation products. The pyrolysis results in pure helium atmospheres, described in Section 2.1.2, showed no CO production; whereas, under thermooxidative conditions with unspecified $\mathrm{O}_{2}$ concentrations, the $\mathrm{CO}$ yield was found to be $29.7 \mathrm{mg} / \mathrm{g}$.

The same polyethylene was also decomposed under depleted $\mathrm{O}_{2}$ atmospheres in a 4.2 \& combustion chamber ( $\mathrm{CAB} 4.2$ ) containing a crucible furnace under the combustion chamber. The chamber was designed to simulate combustion in air with depleted oxygen. As the atmospheric $\mathrm{O}_{2}$ was decreased under restricted flaming conditions, the $\mathrm{CO}$ concentration increased. The average CO yield under limited flame combustion in five tests was $100.2 \mathrm{mg} / \mathrm{g}$. Under these conditions, the co concentration increased as the temperature of the crucible was raised from $500^{\circ} \mathrm{C}$ to $800^{\circ} \mathrm{C}[12]$.

In a second study, Michal decomposed the same high pressure type polyethylene in another combustion chamber ( $C A B 4.5)$ and the gaseous products were measured in an adjoining chamber [14]. This two chamber system was 
designed in an attempt to model the natural flow of toxic combustion products. The total volume of the system was $4.5 \ell$, and samples (1ess than one gram) were combusted in a crucible furnace under both non-flaming and flaming conditions. Table 3 indicates that more $C O$ was formed in the non-flaming mode $\left(500^{\circ} \mathrm{C}\right)$ than in the flaming mode $\left(600^{\circ} \mathrm{C}\right)$. By contrast, the $\mathrm{CO}_{2}$ concentration was considerably higher when the polyethylene was decomposed during flaming combustion than in non-flaming combustion. When compared to other polymeric materials (polypropylene, polystyrene, and polyamide) investigated under nonflaming conditions, the polyethylene was found to produce the most $\mathrm{CO}$ and therefore was considered by the author to be the most dangerous of these materials [14].

In a third study by Michal, a sample of a low density polyethylene (Bralen 03-23) was decomposed in a 650 \& combustion chamber ( $A$ AB 650) designed to accommodate larger amounts of material (up to several grams) and provide more variable conditions for thermal degradation [15]. This combustion chamber was intended to simulate we11-developed fires. Carbon monoxide and carbon dioxide determinations were made after complete combustion of the sample.

There were several differences between the $C A B \quad 650$ and CAB 4.5 systems. In the $C A B 650$ system, a fan was used for mixing the thermal degradation products and for providing more air to the crucible furnace; whereas in the $\mathrm{CAB} 4.5$ system, since there was no forced air supply, the gases moved by natural convection. The ratio of sample weight to the chamber size in $\mathrm{CAB} 650$ was about an order of magnitude lower than that in CAB 4.5 . 
Under the experimental conditions in $\mathrm{CAB} 650$, polyethylene flamed at $500^{\circ} \mathrm{C}$. In the presence of the increased amount of air supplied to the furnace in this test, the $C 0$ production was relatively low, i.e., less than $0.5 \mathrm{mg} / \mathrm{g}$ for all samples tested. However, more $\mathrm{CO}_{2}$ was generated in $\mathrm{CAB} 650$ than that observed under the restricted flame combustion in CAB 4.5, an indication that more thorough thermooxidation occurs in the presence of the greater air supply. Generation of $\mathrm{CO}_{2}$ under these flaming conditions was not found to be temperature dependent since approximately the same amount was measured at $600^{\circ} \mathrm{C}, 800^{\circ} \mathrm{C}$ and $1000^{\circ} \mathrm{C}[15]$.

Morikawa studied the effect of oxygen and water vapor on the generation of $\mathrm{CO}$ from polymeric materials including a polyethylene [13]. The results in nitrogen were discussed in Section 2.1.2. In air, the thermal decomposition of this polyethylene in the presence of water vapor was examined in a tube furnace at three temperatures, $500^{\circ} \mathrm{C}, 600^{\circ} \mathrm{C}$, and $700^{\circ} \mathrm{C}$. The effluent gases were analyzed by GC. The evolution of $\mathrm{CO}$ was generally greater in the presence of water vapor and depended upon the air flow rate. The highest concentration of $\mathrm{CO}$ was observed at $500^{\circ} \mathrm{C}$ at an air flow of $1 \mathrm{l} / \mathrm{min}$ and water vapor flow of $1 \mathrm{~g} / \mathrm{min}$. In this case, the $\mathrm{CO}$ production in the presence of water vapor and air was five times greater than in the absence of water vapor, namely, $500 \mathrm{mg} / \mathrm{g}$ and $100 \mathrm{mg} / \mathrm{g}$, respectively. When the co generation in air $\left(500 \mathrm{mg} / \mathrm{g}\right.$ at $500^{\circ} \mathrm{C}$ ) was compared to that in nitrogen $\left(0 \mathrm{mg} / \mathrm{g}\right.$ at $900^{\circ} \mathrm{C}$ and $50 \mathrm{mg} / \mathrm{g}$ at $1000^{\circ} \mathrm{C}$ ), it was concluded that the evolution of Co seems to be a function of the atmospheric oxygen content, temperature, and water vapor.

The presence of $\mathrm{CO}$ and $\mathrm{CO}_{2}$ has been also determined in several other studies on the oxidative degradation of polyethylenes $[6,8,10,16,17]$. For 
example, during studies of hazards generated in underground mines, Paciorek et a1. measured the amount of $\mathrm{CO}$ and $\mathrm{CO}_{2}$ that was produced when a polyethylene wire insulation (cross linked, pigmented and containing about $0.5 \%$ amine antioxidant) was decomposed in a test designed to simulate the oxidative overheating and combustion that can occur in mines [16]. Gaseous products were analyzed by MS. The major fraction (about one third) of the volatiles detected was $\mathrm{CO}_{2}$. Only small amounts of $\mathrm{CO}$ were observed.

Morimoto et al. measured the toxic gaseous products generated by a series of polymers and cellulosics decomposed under flaming conditions [8]. When a polyethylene sample was burned in a tube furnace at $700^{\circ} \mathrm{C}$ under an air flow of $100 \mathrm{\ell} / \mathrm{hr}$, both $\mathrm{CO}_{2}(738 \mathrm{mg} / \mathrm{g})$ and $\mathrm{CO}(210 \mathrm{mg} / \mathrm{g})$ were detected [8]. The concentration of $\mathrm{CO}_{2}$, but not $\mathrm{CO}$, was found to depend on the air supply rate. When the air flow rate was reduced by $50 \%$, the $\mathrm{CO}_{2}$ levels decreased to $502 \mathrm{mg} / \mathrm{g}$, whereas the CO level remained about the same (195 mg/g).

Boettner et al. studied the products of incomplete combustion of polyethylenes and other plastics which may be produced during waste incineration and could be toxic in real fire situations [17]. Three polyethylene samples were studied: LDPE and HDPE powders and a HDPE in pellet form. Samples were decomposed in a tube furnace under various controlled heating rates and air and oxygen supplies. The major combustion products were identified by IR, minor ones by MS. Although the concentrations of $\mathrm{CO}$ and $\mathrm{CO}_{2}$ depended again upon the heating rates and afr flow rates, $\mathrm{CO}_{2}$ and $\mathrm{CO}$ were the major volatile products formed from all three polyethylene samples. For example, at a heating rate of $5^{\circ} \mathrm{C} / \mathrm{min}$ and air $\mathrm{flow}$ rate of $100 \mathrm{ml} / \mathrm{min}$, the CO and $\mathrm{CO}_{2}$ concentrations ranged from $255-312 \mathrm{mg} / \mathrm{g}$ and $88-213 \mathrm{mg} / \mathrm{g}$, respectively. 
As the heating rate was increased ten fold to $50^{\circ} \mathrm{C} / \mathrm{min}$, the concentration of

Co decreased to $110-208 \mathrm{mg} / \mathrm{g}$ and that of $\mathrm{CO}_{2}$ increased somewhat to

$178-388 \mathrm{mg} / \mathrm{g}$. When oxygen $(40 \mathrm{ml} / \mathrm{min})$ was added to the air flow during the $5^{\circ} \mathrm{C} /$ min experiments, the $\mathrm{CO}$ concentration decreased slightly to $171-179 \mathrm{mg} / \mathrm{g}$ and the $\mathrm{CO}_{2}$ concentrations considerably increased to $753-1842 \mathrm{mg} / \mathrm{g}$.

\subsubsection{Organic Combustion Products}

\subsubsection{Irritants}

When polyethylenes are thermally degraded under oxidative experimental or real fire conditions, complex volatile organic chemical species are produced. The reaction to form these organic volatiles occurs partially within the heated polyethylene material, which has a restricted oxygen supply and partially in the gas phase, which has a rich oxygen supply. Short-chain compounds, such as aldehydes and ketones, are generated predominantly by the gas-phase oxidation of the volatilized hydrocarbons.

In an attempt to identify the volatile breakdown products of toxicological concern, several studies have been performed to detect irritants, such as acrolein, formaldehyde, and low molecular weight carboxylic acids. Morikawa studied the irritant components of smoke from various polymeric and cellulosic materials and found that the evolution of irritants from a polyethylene was relatively large [18]. Polyethylene samples were thermally decomposed in a quartz tube furnace in air. The concentrations of carboxylic acids and acrolein in impinger samples were determined by a GC technique. Formaldehyde was measured by a colorimetric technique using a spectrophotometer. 
Under non-flaming conditions, the amount of irritants from this polyethylene sample increased with oxygen concentration, whereas, under flaming conditions, the concentration of irritants decreased (presumably due to further oxidation and/or decomposition). Maximum evolution of acrolein (350 $\mathrm{mol} / \mathrm{g})$, formaldehyde $(2600 \mu \mathrm{mol} / \mathrm{g})$, and the volatile carboxylic aclds (380 $\mu \mathrm{mol} / \mathrm{g})$ was obtained when the samples of polyethylene were subjected to smoldering combustion at $300-400^{\circ} \mathrm{C}$. Formic acid and acetic acid accounted for the greatest fraction of the detected carboxylic acids.

A limited comparison of the above results to those from a few other nonoxygenated polymers studied by Morikawa showed that this polyethylene appears to generate significant amounts of irritant gases. When compared to wood, several times more acrolein and formaldehyde were generated from polyethylene. Only the evolution of carboxylic acids from polyethylene was equivalent to that generated from wood under similar smoldering conditions [18].

Hodgkin et al. also detected irritant volatile gases in the combustion products of polyethylenes [19]. Four commercial polyethylene samples, LDPE and HDPE pellets, and two LDPE foams, were decomposed in a muffle furnace under a wide range of air flows at temperatures ranging from $500^{\circ} \mathrm{C}$ to $800^{\circ} \mathrm{C}$. The volatile products were analyzed by IR, nuclear magnetic resonance (NMR), GC/MS and wet chemical techniques. The 1ist of products identified included acrolein, formaldehyde, acetaldehyde, and acetic acid (Table 1). These results differed somewhat from those of Morikawa [18] in that the only carboxylic acid detected by Hodgkin et al. was acetic acid and only trace amounts of acrolein were found. These differences may be attributed to the higher experimental temperatures used by Hodgkin et al., and the different chemical sample collection and analysis methods. 
Whereas Morikawa and Hodgkins et al. investigated the generation of Irritant gaseous products from polyethylenes exposed to elevated temperatures (to simulate real fire conditions) [18,19], Hoff et al. studied the decomposition of polyethylenes at lower temperatures (to simulate industrial processing conditions) [10]. Three different commercial LDPE and HDPE samples were decomposed in a tube furnace at $280^{\circ} \mathrm{C}$. Volatile products were detected by GC and MS/GC techniques. At this temperature, the predominant products were the carboxylic acids, formic and acetic, followed by the aldehydes, acrolein, formaldehyde, and acetaldehyde.

The study of Hoff et al. also showed that processing polyethylenes under real manufacturing conditions gives rise to the same volatile irritants as those generated in the laboratory tests. For industrial hygiene purposes, atmospheric measurements were made near machinery processing polyethylenes at temperatures ranging from $140^{\circ} \mathrm{C}$ to $250^{\circ} \mathrm{C}$. The average concentrations of formaldehyde, acetaldehyde, acrolein, formic acid, and acetic acid, however, were very low $\left(<1 \mathrm{mg} / \mathrm{m}^{3}\right)$ and not considered hazardous [10].

\subsubsection{Non-Irritant Organic Compounds}

To assess the toxic hazards associated with the combustion of polyethylenes in fires, many laboratories have looked for volatile organic compounds other than $\mathrm{CO}, \mathrm{CO}_{2}$, and irritant gases in the smoke evolved during thermal decomposition $[6,8,14,16,17,19]$. Both hydrocarbons and oxygencontaining compounds have been identified. Under non-flaming conditions, a variety of aldehydes and ketones are produced; whereas under flaming cond1tions, hydrocarbons predominate and the evolution of aromatic compounds is increased. 
Michal et al. examined the thermal degradation products from a polyethylene decomposed under three conditions: pyrolysis in helium, nonflaming thermooxidation and flaming combustion in air [6]. In addition to the hydrocarbons observed during pyrolysis in helium (see Section 2.1.2), many oxygen-containing compounds were identified in the studies conducted in air (Table 2). In these studies, samples of a commerclal polyethylene (Bralen Z 1907-601) were thermally decomposed in a flow quartz micro-reactor at $350^{\circ} \mathrm{C}$ (non-flaming thermooxidative mode). The volatile products were identified by GC/MS. Under the thermooxidative conditions, the main products were 3-15 carbon aldehydes (48\%). Other minor oxygen-containing products included ketones, acetic acid, ethanol and epoxide. In addition to the oxygencontaining compounds, the volatile products included $25 \%$ olefins and $12 \%$ paraffins. Under flaming conditions conducted under a glass funnel, hydrocarbons represented the most substantial fraction $(\sim 65 \%)$ of the identified volatile products. The yield of aromatic compounds was also greater under flaming than under non-flaming thermooxidative conditions. Among the numerous organic products generated, acrylic acid was considered the most toxic compound identified [6].

Hydrocarbons were found also to represent a substantial portion of the combustion products when samples of a high-pressure type polyethylene (Bralen RB 03-23) were decomposed under flaming combustion conditions in a two-chamber combustion system ( $\mathrm{CAB}$ 4.5) [14]. Propionaldehyde constituted only a minor percentage of the total volatiles and no ketones were detected at all (see Table 2). 
Hodgkins et al. identified many combustion products of polyethylenes decomposed under both flaming and non-flaming oxidative conditions [19]. The organic products from the oxidative flaming experiments included saturated and unsaturated hydrocarbons with a chain length ranging from two to twenty-three carbons. Only a few of the low molecular weight hydrocarbons were actually identified (Table 1). Most of the products identified were in the higher molecular weight range and consisted of aldehydes, ketones and aromatic compounds. Basically, the same product pattern was observed for four different samples of polyethylene decomposed under similar conditions. The composition of the hydrocarbons varied with changes in temperature but not with changes in air flow rates. The major changes noted as the temperature increased were the increase in the aromatic hydrocarbons, benzene and toluene, and the large decrease in acetone production.

Boettner et al. also noted that the composition of the organic volatile products was similar for different polyethylenes [17]. When three different polyethylene samples (LDPE pellets, HDPE powder and HDPE pellets) were heated in a tube furnace under various combustion conditions, the organic compounds identified included mostly straight-chain saturated and unsaturated hydrocarbons containing one to six carbon atoms (Table 1). Unsaturated hydrocarbons predominated over saturated products. The only oxygen-containing compounds detected were methanol and acetaldehyde.

The presence of low molecular weight hydrocarbons in the combustion products of a polyethylene wire insulation was also observed by Paciorek et a1. [16]. Methane, ethylene, ethane, propane, and benzene were detected as minor components of the smoke produced when a commercial polyethylene wire 
insulation was decomposed in a "stagnation" burner arrangement in which preheated air was passed over the test specimen.

Morimoto et a1. [8] performed a detalled study on the low molecular weight hydrocarbons generated from polyethylene decomposed under different ventilation conditions at a constant temperature of $700^{\circ} \mathrm{C}$. In air, the main products detected by IR were methane, ethylene, and acetylene. At an air flow rate of $50 \mathrm{l} / \mathrm{hr}$, the concentrations for methane, ethylene, and acetylene were $65 \mathrm{mg} / \mathrm{g}, 187 \mathrm{mg} / \mathrm{g}$ and $10 \mathrm{mg} / \mathrm{g}$, respectively. Only the concentration of acetylene was found to be dependent on oxygen availability. When the air flow through the combustion chamber was doubled from $50 \mathrm{l} / \mathrm{hr}$ to $100 \mathrm{l} / \mathrm{hr}$, the acetylene concentration increased from $10 \mathrm{mg} / \mathrm{g}$ to $34 \mathrm{mg} / \mathrm{g}$, respectively.

In industrial processing, polyethylenes are subjected to temperatures significantly lower than those used in the studies described above. During tests to examine industrial processing hazards, Hoff et al. studied the decomposition of LDPE and HDPE type polyethylenes over a temperature range of 265 to $290^{\circ} \mathrm{C}$ using a tube furnace [10]. The volatile organics were analyzed by GC and MS techniques. Hoff et al. identified a total of 44 products representing hydrocarbons, alcohols, aldehydes, ketones, acids, lactones, cyclic ethers, and cyclic esters. Essentially the same products were formed for both types of polyethylene tested. This agrees with results of Hodgkin et al. [19] and Paciorek et al. [16]. Contrary to the non-flaming and flaming studies conducted at higher temperatures $[6,14,19]$, the oxygen-containing organic compounds constituted the majority and hydrocarbons the minority of compounds detected. 


\subsubsection{Polycyclic Aromatic Hydrocarbons}

Polycyclic aromatic hydrocarbons (PAHs) are not considered acute toxicants; however, some have been shown to be carcinogens. Since generation of PAHs is generally associated with smoke and soot particulates, PAHs may be of importance in long term or repetitive exposures to fire gases (e.g., in the case of fire fighters). The presence of PAHs in the smoke of polyethylenes has been demonstrated in a number of studies $[11,20,21]$. Morikawa studied the evolution of PAHs, especially benzo(a)pyrene during pyrolysis under inert conditions (see Section 2.1 .2 for details) and oxidative combustion of polyethylene and other materials $[11,20]$. Samples of a polyethylene were decomposed in a tube furnace at several temperatures ranging from 600 to $900^{\circ} \mathrm{C}$ under varying airflow rates [20]. PAHs were determined by GC analysis of the extracts of the collected soot and solid products. Evolution of condensed matter from this polyethylene was highest at 600 and $900^{\circ} \mathrm{C}$ and 1 ower at 700 and $800^{\circ} \mathrm{C}$. The corresponding yields of benzo(a)pyrene increased with increasing temperatures (from $0.1 \mathrm{mg} / \mathrm{g}$ at $600^{\circ} \mathrm{C}$ to $1.3 \mathrm{mg} / \mathrm{g}$ at $900^{\circ} \mathrm{C}$ ). In addition to benzo(a)pyrene, five other PAHs, anthracene, fluoranthene, pyrene, benzo(a)anthrathene, and benzo(c)pyrene, were detected in the soot and solid products from this polyethylene.

The evolution of PAHs is normally associated with soot formation during fires. However, Morikawa found that formation of benzo(a)pyrene is not always accompanied by the formation of soot and solid products as the consistency of the condensed matter may vary over the temperature range. More benzo(a)pyrene was observed to evolve from a polyethylene than from a polystyrene, even though the polystyrene produced three to four times more soot than the poly- 
ethylene [20]. In addition, when the polyethylene was decomposed at $900^{\circ} \mathrm{C}$ (a non-sooting temperature) in nitrogen, benzo(a)pyrene was also produced [11].

PAHs in the smoke from samples of a polyethylene (containing additives $5 \%$ by weight) exposed to radiant thermal fluxes of $4.3 \mathrm{~W} / \mathrm{cm}^{2}$ (non-flaming) and $5.0 \mathrm{~W} / \mathrm{cm}^{2}$ (flaming) were also detected by Zinn et al. [21]. Chemical characterization of the smoke particulates was performed by HPLC, GC, and MS/GC. The PAH yields were $0.045 \mathrm{mg} / \mathrm{g}$ in the non-flaming tests and $0.025 \mathrm{mg} / \mathrm{g}$ in the flaming tests. The principal compounds detected in the non-flaming combustion of this polyethylene were anthracene and/or phenanthrene and pyrene; in the flaming mode, the major product was pyrene (Table 4 ).

Compared to other polymers (polystyrene, polymethylmethacrylate and polypropylene) studied by Zinn, and decomposed under similar conditions, the polyethylene generated the greatest quantities of PAHs. Again, the generation of PAHs did not correlate with soot formation as polystyrene generated the most soot but only traces of PAHs [21]. These results agree well with those of Morikawa $[11,20]$.

\subsubsection{Free Radicals}

When polyethylenes are decomposed in a fire or processed at elevated temperatures in air, the heated polymer undergoes an oxidative thermal degradation which proceeds partly through alkyl, peroxy, and alkoxy radical formations. Free radicals from the combustion of polymers have been observed to cause injuries to cells in tissue cultures [22] and are of toxicological concern due to their high reactivity. 
Two research groups have detected free radicals by electron spin

resonance (ESR) spectroscopy from the industrial processing of polyethylenes $[10,23]$. These studies indicated that the detected species were alkoxy and peroxy radicals formed by decomposing polyethylenes in oxygen. In addition to free radicals, one of these groups also detected the presence of hydroperoxides [10]. The concentration of free radicals and peroxides in the environment were estimated roughly to be about the same as that found for the total aldehydes $\left(\sim 2.2 \mathrm{mg} / \mathrm{m}^{3}\right)[10]$. Even though both these studies demonstrated that processing of polyethylenes gives rise to free radicals, free radicals are normally very short-lived species, and there is no clear evidence that the free radicals constitute a hazard when polyethylenes are involved in real fires.

\section{TOXICOLOGY}

Several bioassay methods have been used to assess the acute toxicity of fire gases. In these tests, animals are exposed to smoke and toxic gases and either death or incapacitation serves as the biological endpoint. Most test procedures include some chemical analysis of specific toxicants of interest. The various toxicity test methods have been described in detail by Kaplan et a1. [28].

In the reviewed literature, seven different toxicity test procedures were utilized to assess the toxicity of combustion products from polyethylenes. A brief summary of the five main methods used and the biological endpoints that have been evaluated is given below. 


\begin{tabular}{|c|c|c|c|c|c|}
\hline \multirow[b]{2}{*}{ Method } & \multicolumn{3}{|c|}{ Le thality } & \multicolumn{2}{|c|}{ Incapacitation } \\
\hline & $\mathrm{LC}_{50}$ & $\begin{array}{l}\text { No. Animals } \\
\text { Affected }\end{array}$ & $\begin{array}{l}\text { Time to } \\
\text { Death }\end{array}$ & $\mathrm{IC}_{50}$ & $\begin{array}{c}\text { Time to } \\
\text { Incapacitation }\end{array}$ \\
\hline DINa & & $\mathrm{x}$ & & & \\
\hline USF b & & $\mathrm{x}$ & $\mathbf{x}$ & & $\mathrm{x}$ \\
\hline FAA/CAMIC & & & $\mathrm{x}$ & & $\mathrm{x}$ \\
\hline Dowd & $\mathrm{x}$ & $\mathrm{x}$ & & & \\
\hline CMIRe & $\mathrm{x}$ & & & $\mathrm{x}$ & $\mathrm{x}$ \\
\hline
\end{tabular}

Method developed in response to the German Commission of Standards

${ }^{b}$ University of San Francisco

CFederal Aviation Administration

dow Chemical Company

e Carnegie Mellon Institute of Research

\subsection{DIN Toxicity Test Method}

The toxicity of the combustion products from various materials, including polyethylenes, has been evaluated by two groups of workers using several variations of the DIN method. Briefly, the DIN Draft 53436 test method uses a dynamic flow system in which materials of equal volume or equal weight per unit length are decomposed in a quartz tube. The tube is heated by an externally moving $(1 \mathrm{~cm} / \mathrm{min})$ furnace at fixed temperatures between $200^{\circ} \mathrm{C}$ and $600^{\circ} \mathrm{C}$. The decomposition products are diluted with air at chosen flow rates. Chambers of various designs have been used to expose animals in the head-only or whole-body mode. These exposures usually last for 30 minutes and lethality is the usual biological endpoint.

An early version of the DIN method was used by Hoffmann and Oettel to compare the toxicity of the thermal decomposition products of building materials [29]. They demonstrated that ranking materials based solely on the chemical analyses of a few of the decomposition products may be misleading and does not correspond with results from toxicological experiments on animals. 
In these experiments, a polyethylene (without a filler) was decomposed at $100^{\circ}$ increments between 200 and $600^{\circ} \mathrm{C}$ with an air flow rate of $100 \mathrm{l} / \mathrm{h}$. The pyrolysis products were further diluted with an $100 \mathrm{\ell} / \mathrm{h}$ air supply. Rats were exposed in the whole-body mode for 30 minutes. The blood carboxyhemoglobin ( $\mathrm{COHb})$ levels in the experimental animals were determined immediately after the exposure. The results of these experiments showed that when five gram samples of a polyethylene were pyrolyzed, $100 \%$ mortality occurred at temperatures of $400^{\circ} \mathrm{C}$ and greater, whereas no deaths were observed at lower temperatures (Table 5). Since COHb concentrations in the dead animals ranged from 79 to $85 \%$, the lethalities were attributed by Hoffmann and Oettel to Co [29].

Hoffmann and Oettel also compared the toxicity produced by the thermal degradation of the same polyethylene to that of other conventional building materials tested at the same sample weight under similar conditions. The toxicity of these materials, cellulose, rigid poly(vinyl chloride) (PVC), and pine, were classified 1,2 , and 3 , respectively, according to a Swiss classification (where 1 indicates the most toxic case). The polyethylene that was tested was assigned a toxicity classification of 4. Based on animal test results, temperatures above $400^{\circ} \mathrm{C}$ generated decomposition products with the same toxicity from all four materials. However, at $300^{\circ} \mathrm{C}$, the decomposition products from the polyethylene were less toxic than those from the other three materials. At $200^{\circ} \mathrm{C}$, cellulose was the only material to produce toxic combustion products [29].

In another study, Hoffmann and Sand investigated the toxicity of the decomposition products from two types of polyethylene (HDPE and LDPE) and compared the results to those from pine wood [30]. Conditions were set such 
that sublethal concentrations of $\mathrm{CO}$ were generated. In these experiments, ten grams of the polyethylenes were decomposed at $600^{\circ} \mathrm{C}$. The air supply through the furnace was $450 \mathrm{l} / \mathrm{h}$ and an additional air supply of $450 \mathrm{l} / \mathrm{h}$ was used for dilution of the pyrolysis products in the exposure chamber. The co concentrations were determined by Draeger tubes ${ }^{2}$ and were less than 1000 ppm. The COHb levels in the blood at the end of the 30 minute exposures were 27 percent and 33 percent for the LDPE and HDPE, respectively, and no deaths occurred. Under the same test procedure, pine wood generated about $2000 \mathrm{ppm} \mathrm{CO}$, COHb levels of $51 \%$, and also no deaths. The authors concluded that under these test conditions, the combustion products from these polyethylenes appear to be no more toxic than those from pine wood and that in a real fire, the toxicological risk from the fire gases of polyethylenes is no greater than that of pine wood.

Herpol et al. used the DIN toxicity test method to investigate whether synthetic materials are more dangerous when involved in fires from a toxicological point of view than natural materials [32-34]. The polyethylene samples included in this study are listed below:

No. 5 and $\mathrm{K} 9$ - Low density sheets

No. 6 or K10 - High density sheet A

No. 7 - High density sheet B

No. 8 - Low density granules

K11 - Tubing (treated with fire retardant)

\footnotetext{
2 It should be noted that the use of colorimetric tubes, such as Draeger tubes, provides unreliable and, at best, semiquantitative results, primarily because other combustion gases may interfere in the analysis. The temperature of the gas being sampled also has been noted to have an effect on the results [31].
} 
These materials were decomposed at three temperatures, 400, 600 and $800^{\circ} \mathrm{C}$, in a furnace through which an air flow of $200 \mathrm{l} / \mathrm{h}$ was passed. The combustion products were further diluted by an additional air flow of $200 \ell / \mathrm{h}$ before entering the exposure chamber in which rats were exposed in a whole body mode for 30 minutes. Lethality (as measured by the cessation of respiration) was the biological endpoint.

The polyethylene samples flamed in all except a few tests at $400^{\circ} \mathrm{C}$. At $600^{\circ} \mathrm{C}$, all of the polyethylene samples were about equally toxic and caused 92-100\% mortality. At 400 and $800^{\circ} \mathrm{C}$, samples 5 and $\mathrm{K} 9$ were more toxic than samples $\mathrm{K} 10$ and $\mathrm{K} 11$ (FR) (Table 6). The COHb levels in the blood of dead rats ranged between 48 and 79 percent. The co concentration-time products for 30 minutes ranged from 29,000 to $189,000 \mathrm{ppm}{ }^{\circ}$ min in those experiments in which deaths occurred. In an earlier study of lethalities from pure co in air, Herpol et a1. found that no deaths occurred at Co concentration-time products up to $120,000 \mathrm{ppm}^{\circ}$ min and 100 percent of the animals did not die until $210,000 \mathrm{ppm}^{\circ} \mathrm{min}$ was reached [35]. In the pure CO experiments in which all the animals died, the mean $\mathrm{COHb}$ ranged from $58-71 \%$. In the experiments on polyethylenes, most of the co concentration-time products are lower than the lethal Co concentration-time products seen in the pure Co tests, an indication of the presence of other toxicants.

The $\mathrm{CO}_{2}$ concentration-time products in Table 6 ranged from 26.0 to 191.8 percent·min except for sample $\mathrm{Kll}(\mathrm{FR})$ which had an $\mathrm{CO}_{2}$ concentration-time product of 0.5 percent.min at $400^{\circ} \mathrm{C} . \mathrm{A} \mathrm{CO}_{2}$ concentration-time product greater than 75 percent'min will increase the rate of respiration [35]. In these experiments, however, the respiration of rats decreased drastically even when 
$\mathrm{CO}_{2}$ concentration-time products were above 100 percent $\min (\mathrm{Table} 7)$. This reduction suggests the presence of irritants in the combustion products.

Comparison of results (shown below) obtained with two wood products decomposed in the DIN test method showed that some of the samples of polyethylene (not fire retarded) appeared to be more toxic at $800^{\circ} \mathrm{C}$, but had about the same degree of toxicity at 400 and $600^{\circ} \mathrm{C}$ [33].

\begin{tabular}{|c|c|c|c|}
\hline \multirow[b]{2}{*}{ Sample } & \multicolumn{3}{|c|}{ Percent Mortality at } \\
\hline & $400^{\circ} \mathrm{C}$ & $600^{\circ} \mathrm{C}$ & $800^{\circ} \mathrm{C}$ \\
\hline $5, \mathrm{~K} 9$ & 94 & 94 & 100 \\
\hline $6, \mathrm{~K} 10$ & 67 & 100 & 39 \\
\hline 7 & & 92 & \\
\hline 8 & & 100 & \\
\hline beech & 72 & 54 & 17 \\
\hline poplar & & 100 & 28 \\
\hline
\end{tabular}

To assess the hazard produced from the decomposition of a material, Herpol proposed the use of a "toxicity index" (TX) based on a mathematical expression which takes into consideration the observed mortality and exposure time under the most toxic conditions [34,36,37]. A good correlation was shown to exist between the TX and $\mathrm{LT}_{50}$ values (time necessary to kill 50 percent of the rats). The maximum TX values for the three polyethylenes tested (K9, K10, $\mathrm{Kll}(\mathrm{FR}))$ ranged from 30 to 48 . These values indicated a higher overall toxicity for the polyethylene samples than for the poplar and beech wood samples (results shown below) [34]. 


$\begin{array}{lr}\text { K9 } & 48.00 \\ \text { K10 } & 29.53 \\ \text { K11 (FR) } & 30.93 \\ \text { beech } & 8.80 \\ \text { poplar } & 16.93\end{array}$

\subsection{University of San Francisco (USF) Toxicity Test Method}

The USF test method has been used by Hilado et al. to evaluate the toxicity of the thermal decomposition products from a great number of commercial materials, including polyethylene. The test method involves exposing four mice in the whole-body mode to the thermal degradation products from one gram samples decomposed in a tube furnace. The temperature is either increased from 200 to $800^{\circ} \mathrm{C}$ at a rate of $40^{\circ} \mathrm{C} / \mathrm{min}$ or fixed at a temperature ranging from 200 to $800^{\circ} \mathrm{C}$. The experiments are conducted with or without a forced air supply. Animals are exposed for 30 minutes or until the time of death of the last surviving animal. Biological endpoints are average times to incapacitation $\left(\mathrm{T}_{\mathbf{i}}\right)$ as indicated by staggering, prostration, convulsions, and collapse, and time to death $\left(\mathrm{T}_{\mathrm{d}}\right)$ as indicated by cessation of movement and lack of respiration.

The results of the evaluation of several samples of polyethylene decomposed in the USF furnace set in the rising temperature mode without any added air supply are presented in Table 8 . The average times to incapacitation ranged from $11.54 \pm 0.62$ to $15.52 \pm 4.44$ minutes and average times to death ranged from $13.99 \pm 0.85$ to 24.69 minutes. In most tests, death occurred two to six minutes after incapacitation (as indicated by stagger1ng). The average times and standard deviations were calculated from the mean of two 
or more experiments and are not indicative of the variability of the animals within any one test.

The relative toxicity of polyethylenes is highly dependent on the conditions of combustion (temperature and air flow rate). Changing from the rising temperature program to a fixed temperature mode at $800^{\circ} \mathrm{C}$ results in shorter times to animal responses, i.e., higher toxicity [39]. This effect is attributed to the more rapid generation of toxicants from polyethylenes when decomposed at $800^{\circ} \mathrm{C}$ as compared to the rising temperature program. Progressive increases in toxicity were also observed in the fixed temperature mode as the temperature was increased [40].

When the polyethylenes were decomposed under a forced air supply, the times to death and times to incapacitation were generally shorter than when the polyethylenes were decomposed in the static mode [41]. The effects of the temperature regime and ventilation conditions on the times-to-death from the exposures to the combustion products from a polyethylene are summarized in Table 9 [42].

In a study on the lethal effects of $\mathrm{CO}$ in air, Hilado and Cumming found that the time-to-death from $10,000 \mathrm{ppm}$ CO was about five minutes [43]. When polyethylene samples were decomposed with the USF test method using either of the two temperature modes, GC gas analysis of the chamber atmospheres at the time of death of the last surviving animal showed the presence of relatively high concentrations of $\mathrm{CO}$, methane, and ethylene (Table 10). The CO concentrations ranged from 9,155 to $15,050 \mathrm{ppm}$ (rising temperature mode) and from 565 to $16,560 \mathrm{ppm}$ (fixed temperature mode). From the results in Table 10, it 
appears that $C O$ could be the principal toxicant in the combustion gas mixture from the polyethylenes decomposed in the rising temperature mode and in the experiments in the fixed mode at 500,600 , and $800^{\circ} \mathrm{C}$ without forced air. At 300 and $400^{\circ} \mathrm{C}$, where the Co concentrations were below $3000 \mathrm{ppm}$, other gases most likely contributed to the observed deaths.

The role of $\mathrm{CO}$ in the combustion gas mixture was estimated by a concentration-time relationship or "death product" (DP), which was defined as

$$
D P=\int_{0}^{t} C d t
$$

where $C$ is the concentration of $\mathrm{CO}$ at time $t$ [44]. Hilado and Cumming determined the critical DP for Co to be 47,240 $\pm 14,980 \mathrm{ppm}^{\circ}$ min [43]. Tests were terminated upon death of the last surviving animal or 30 min. The DP values for $\mathrm{CO}$ from five polyethylene samples decomposed with the rising temperature mode were found to range from 41,880 to 74,650 ppm *min [44]. For three other polyethylene samples decomposed at $800^{\circ} \mathrm{C}$, the DP values ranged from 60,290 to $95,390 \mathrm{ppm}^{\circ} \mathrm{min}$ [45]. The range of DP values calculated for these polyethylenes suggest that $C 0$ was probably the principal toxicant.

\subsection{Federal Aviation Administration (FAA/CAMI) Toxicity Test Method}

The toxicity of the thermal degradation products from various alrcraft cabin materials, including a fire retarded polyethylene flotation cushion, has been evaluated by Crane et al. using the FAA toxicity test method [46]. This test method utilizes a static system consisting of a tube furnace connected to an exposure chamber in which three rats are exposed in the whole-body mode for 
30 minutes. The combustion products, generated from $0.75 \mathrm{~g}$ samples decomposed at $600^{\circ} \mathrm{C}$, are recirculated between the furnace and the animal chamber during the exposure. Separate rotating activity wheels in which the rats are forced to run or walk continuously are used to determine the time to incapacitation $\left(T_{1}\right)$ and time to death $\left(T_{d}\right)$. Rats are considered incapacitated when they start to slide or tumble in the rotating cages and dead when visible respiration ceases. When the animals were exposed to the combustion products from a fire retarded rigid polyethylene foam, the mean observed response times for $T_{i}$ and $\mathrm{T}_{\mathrm{d}}$ were $6.66 \pm 0.85$ minutes and $10.26 \pm 0.62$ minutes, respectively. For comparison purposes, Crane et al. converted the observed response times to "standard" response times (1.e., the values were normalized to a 200 gram rat and $1.000 \mathrm{gram}$ fuel load). The normalized values were 5.25 minutes for $\mathrm{T}_{1}$ and 8.08 minutes for $T_{d}$. That the "standard" $T_{1}$ value for this polyethylene foam was within the range of $T_{1}$ values ( 4.29 to $5.55 \mathrm{~min}$ ) determined for 6 other commercial foams is an indication that the toxicity of this polyethylene was about equal to that of other foams used for the same end purpose [46].

The FAA/CAMI screening test method was also used by Hilado et al. to evaluate a series of materials and to compare the test results with those obtained by the USF test method [47]. The sample evaluated was a low density polyethylene (referred to as PE 1 in section 3.2). All animals died when a $0.75 \mathrm{~g}$ sample of the polyethylene was decomposed at $600^{\circ} \mathrm{C}$. The average times to incapacitation and to death were $4.88 \pm 0.29 \mathrm{~min}$ and $8.03 \pm 0.08 \mathrm{~min}$, respectively. About $10,000 \mathrm{ppm}$ of $\mathrm{CO}$ were detected in the exposure atmosphere. This polyethylene produced the most toxic degradation products when compared to three other materials tested according to the FAA/CAMI method (i.e., in degree of toxicity, polyethylene > polycarbonate > ABS > 
polystyrene). In contrast, this polyethylene ranked third when tested with the USF method using the rising temperature program $\left(40^{\circ} \mathrm{C} / \mathrm{min}\right.$ from 200 to $800^{\circ} \mathrm{C}$ ) with no forced air flow [47].

\subsection{The Dow Chemical Company Test Method}

Potts et al. studied the toxicity of several polyethylene formulations decomposed under non-flaming (oxidative pyrolysis) and flaming conditions [26]. The test method employed was developed by the Dow Chemical Company specifically to evaluate smoke toxicity [48]. Rats were exposed for 30 minutes in a whole-body mode to degradation products generated in a quartz cup furnace located within the exposure chamber. All the smoke generated in the furnace was kept in the exposure chamber (1.e., static system). The rats were observed for any abnormal symptoms (e.g•, irritation, breathing irregularity, and nasal discharges) and mortality. LC $_{50}$ values (the concentration of material consumed $(\mathrm{mg} / \ell)$ that caused $50 \%$ of the animals to die) were calculated for deaths that occurred during the 30 minute exposure and a 14 day post-exposure period. The chamber atmosphere was analyzed for $\mathrm{CO}, \mathrm{CO}_{2}$, and $\mathrm{O}_{2}$ by GC and for acrolein by GC/MS and colorimetric methods using a spectrophotometer.

Toxicity experiments were performed on three commercial samples of polyethylene [ETHAFOAM 220 foam, XFS4101 foam (which was fire retarded), and DOW 520 pellets] [26]. Three to six gram samples decomposed in the flaming mode produced signs of abnormal behavior and deaths during the 30 minute exposures (no rats died during the 14 day post-exposure period). In these experiments, the average $C 0$ concentrations ranged from 1500 ppm to 4100 ppm, 
$\mathrm{O}_{2}$ levels from $11 \%$ to $15 \%$, and acrolein concentrations from 3 to 23 ppm. The lethalities were attributed to $\mathrm{CO}$ poisoning together with marked oxygen depletion.

The non-flaming experiments, which were carried out at temperatures just below the auto-ignition temperatures of the polyethylene samples $(0.35$ to 2 grams), produced signs of breathing difficulties and eye irritation. Lethalities occurred only during the post-exposure period (in most cases, within 16 to $48 \mathrm{hrs}$ ). In these experiments, the average co concentrations ranged from 100 to 2200 ppm, acrolein concentrations were between 19 to $155 \mathrm{ppm}$, while $\mathrm{O}_{2}$ levels remained above $19 \%$. Gross pathologic examinations of the animals showed lesions in the upper and lower respiratory system. The lethalities were attributed principally to the concentrations of acrolein in the exposure atmosphere. To verify that the levels of acrolein measured in these experiments can cause deaths as a result of a 30 minute exposure, Potts et al. conducted control exposures to acrolein in air. Since the LC $_{50}$ for acrolein was determined to be in the range of 45-95 ppm and most of the lethalities occurred within 24-48 hours following the exposure, it seems reasonable to assume that the acrolein played a major role in the deaths of the rats [26].

The polyethylene foams examined by Potts et al were found to be more toxic in the non-flaming mode than in the flaming mode (Table 11). (No $\mathrm{LC}_{50}$ values were calculated for exposures with polyethylene sample DOW 520). When compared to cellulosic materials tested by the same method in the flaming mode, the decomposition products from these polyethylenes [ $\mathrm{LC}_{50}$ (30 min + 14 day) values of 35 and $31 \mathrm{mg} / \ell$ ] were found to be about as toxic as those 
from wood $\left[L_{50}(30 \mathrm{~min}+14\right.$ days $\left.)=35.0 \mathrm{mg} / \ell\right]$; whereas, in the non-flaming mode, the decomposition products from these polyethylenes $\left[\mathrm{LC}_{50}(30 \mathrm{~min}+14\right.$ day) values of 6 and $5 \mathrm{mg} / \mathrm{l}$ ] were more toxic than those from wood [ $\mathrm{LC}_{50}$ (30 $\mathrm{min}+14$ days $)=22 \mathrm{mg} / \ell]$. In contrast, the toxicity of a polyethylene wire insulation in the non-flaming mode as determined by Levin et al. using the National Bureau of Standards (NBS) toxicity test method [49] appeared to be much less toxic than that found by Potts et al. The results of Levin et al. showed a non-flaming $\mathrm{LC}_{50}$ (30 min + 14 day) value greater than $75 \mathrm{mg} / \ell$ [50]. The difference in the results of Levin et al, and those of Potts et al. indicate that the high toxicity of the foams examined by Potts et al are not necessarily characteristic of polyethylenes in general.

Potts et a1. also found that the acrolein concentrations from the nonflaming decomposition of wood were lower than those formed from these polyethylenes (e.g., 43 ppm for a 6 gram sample of wood vs 155 ppm for a 2 gram sample of polyethylene) [48]. Therefore, acrolein may be contributing to the post-exposure deaths from these polyethylenes.

Polyethylenes produce high concentrations of acrolein only over a narrow temperature range. Decreasing the pyrolysis temperature $40^{\circ} \mathrm{C}$ below the autoignition temperature reduced the acrolein concentrations from a five gram sample of polyethylene to $<2 \mathrm{ppm}$ and produced no deaths. Closer to the autoignition temperature, 65 to $97 \mathrm{ppm}$ of acrolein were generated and all the test animals died. Potts et al. point out that since polyethylenes are lethal over the very narrow pyrolysis temperature range of approximately $40^{\circ} \mathrm{C}$, the time in which lethal effects can be produced in real fire situations is probably very short. 


\subsection{Large Scale Tests}

The hypothesis of Potts et al. was examined in large-scale tests where approximately the same sample weight of polyethylene per room volume ratio $(13.6 \mathrm{mg} / \ell)$ noted to produce $100 \%$ rat mortality in the Dow smal1-scale test was decomposed [24]. In the first series of experiments, blocks of the same polyethylene foams, ETHAFOAM 220 and XFS-4101 (FR), were decomposed by radiant heat fluxes $\left(\geq 25 \mathrm{~kW} / \mathrm{m}^{2}\right)$ either under flaming or non-flaming conditions in a $70 \mathrm{~m}^{3}$ room. Rats were exposed to the smoke in rooms adjacent to the burn room. In the large-scale non-flaming tests, on 1 y $5 \%$ of the foam was consumed and in the flaming experiments, only about one third of the foam was decomposed. The concentration of acrolein in the vicinity of the rats was less than $10 \mathrm{ppm}$ for the flaming tests and less than $5 \mathrm{ppm}$ for the non-flaming tests. The exposed rats showed no ill effects in either case.

In a second series of tests, approximately $18 \mathrm{~kg}$ (40 1bs) of the same two polyethylene foams were burned in the flaming mode in a building of about $1000 \mathrm{~m}^{3}$ in volume. Rats were placed in the building and were exposed to the combustion products from the fire for a total time of 30 minutes. The small amount of acrolein (1ess than $15 \mathrm{ppm}$ ) produced no $i 11$ effects in the rats. Heat blisters were noted at the edges of rats' ears due to temperatures which briefly reached 60 to $80^{\circ} \mathrm{C}[24]$. The investigators concluded that the acrolein concentrations produced in certain "real" fires involving polyethylenes would probably not constitute a significant hazard.

To evaluate whether polyethylene-based materials pose an unreasonable hazard in a "real" fire, Kuhn et al. studied the production of the toxic 
gases, co and acrolein, from polyethylene foams decomposed under both nonflaming and flaming conditions in full-scale fire tests not involving animals [24]. In the first series of experiments about $320 \mathrm{~kg}$ (710 $1 \mathrm{bs}$ ) of the same two brands of polyethylene, ETHAFOAM 220 and XFS-4101 (FR), were burned in a building of about $1000 \mathrm{~m}^{3}$ in size. The fire, after becoming well developed, was extinguished with water. The concentration of acrolein, which was measured in the burn room prior to the extinguishment, was estimated to be less than $15 \mathrm{ppm}$ for both foams. (The presence of soot may have interfered with the spectrophotometric colorimetric technique used.)

In the second series of tests, the relative hazard of acrolein in fullscale tests was compared to that of $\mathrm{CO}$. One to nine cartons (each containing approximately 50 lbs) of the same two brands of polyethylene were burned in a $34 \mathrm{~m}^{3}$ room connected to a corridor. The maximum concentrations of $\mathrm{co}$ and acrolein detected in the corridor were $14000 \mathrm{ppm}$ and $15 \mathrm{ppm}$, respectively. The $\mathrm{LC}_{50}$ (30 min and 14 day) value for $\mathrm{CO}$ as determined for $\mathrm{CO}$ in rats is $4600 \mathrm{ppm}$ [25] and that for acrolein is in the range of 45-95 ppm [26]. Other studies of five minute exposures of baboons to acrolein in air showed that 500 ppm produced no deaths either during or following the exposures; whereas, concentrations of about $1000 \mathrm{ppm}$ produced some post-exposure deaths [27]. Therefore, the large-scale test results suggest that the acrolein concentrations generated in "real" fires involving polyethylene foams were not toxicologically significant; whereas the levels of $\mathrm{CO}$ are of toxicological concern. 


\subsection{Miscellaneous Tests}

Gad and Smith used a test method developed at the Carnegie Me11on Institute of Research (CMIR) to evaluate the influence of heating rates on the toxicity of the decomposition products from a HDPE [51]. The experimental procedure involved exposing the whole-bodies of rats to the thermal degradation products generated in a furnace heated by a radiant IR source. The furnace and the exposure chamber were interconnected so that the animals rec $\in$ ived a static exposure. $\mathrm{CO}$ and $\mathrm{CO}_{2}$ were monitored during the exposure by IR and the total hydrocarbons were measured by flame photometry. A motordriven rotating activity wheel was used to determine incapacitation and lethality. The $\mathrm{LC}_{50}$ and $\mathrm{IC}_{50}$ values (the concentrations that killed or incapacitated $50 \%$ of the test animals exposed for 30 minutes) were based on the weight of the polyethylene sample volatilized.

Six rats were exposed for 30 minutes to the decomposition products from HDPE samples heated at rates of $20,30,40$ and $50^{\circ} \mathrm{C} / \mathrm{min}$ starting from an ambient temperature of $25^{\circ} \mathrm{C}$. The polyethylene flamed early when exposed to the higher heating rates $\left(40\right.$ and $\left.50^{\circ} \mathrm{C} / \mathrm{min}\right)$. The experimental results were influenced by the change in heating rate as well as by the mode of combustion. The production of $\mathrm{CO}$ increased as the heating rate increased (e.g., the maximum CO concentration from a two gram sample increased from 800 ppm at $20^{\circ} \mathrm{C} / \mathrm{min}$ to $7300 \mathrm{ppm}$ at $\left.50^{\circ} \mathrm{C} / \mathrm{min}\right)$. However, much more of the sample was decomposed at the higher heating rates. A similar trend was observed for total hydrocarbons. 
The $\mathrm{LC}_{50}$ and $\mathrm{IC}_{50}$ results calculated for 30 minute exposures at different heating rates in both the flaming and non-flaming modes are summarized in Table 12. In the non-flaming mode, the toxic effect of the combustion products from the polyethylene increases slightly (lower value indicates increased toxicity) at the higher heating rates. In the flaming mode, the combustion products from the polyethylene appear to be less toxic as the $\mathrm{LC}_{50}$ values increased by almost a factor of two over the non-flaming results at the lower heating rates. In most cases, the lethalities appear to be attributable to the CO concentrations. Comparing the polyethylene results and those of Douglas fir, Gad and Smith concluded that over the range of experimental conditions, the combustion toxicity of this HDPE was not greater than that of Douglas fir, a reference material commonly used for comparison.

Kishitani and Nakamura used a dynamic system and time based animal model (similar to that employed by other Japanese research groups) to evaluate the toxicity of combustion products of building materials [52]. A polyethylene was decomposed in a tube furnace at 350,500 and $750^{\circ} \mathrm{C}$ (temperatures to which materials would be subjected during the initial stages of a fire). Flaming occurred at $750^{\circ} \mathrm{C}$. One mouse at a time in a whole-body mode was exposed to the combustion products in an adjacent chamber for 15 minutes, a time period which was estimated as the time required to evacuate a multi-storied building. Surviving mice were kept and observed for one week following the tests. A vibration sensor during the exposures was used to detect movement of the mouse. Time of death in minutes or days, as indicated by the cessation of respiration, was the biological endpoint. 
The maximum concentrations of $\mathrm{CO}$ generated by the degradation of ten gram samples of a polyethylene were $6500 \mathrm{ppm}$ at $350^{\circ} \mathrm{C}, 3900 \mathrm{ppm}$ at $500^{\circ} \mathrm{C}$, and $1800 \mathrm{ppm}$ at $750^{\circ} \mathrm{C}$. No deaths occurred from the exposure to the $750^{\circ} \mathrm{C}$ (flaming) combustion products, but all mice died from the non-flaming combustion products generated at $350^{\circ} \mathrm{C}$ and $500^{\circ} \mathrm{C}$. All those deaths, except one, occurred 1 to 3 days following the exposure. The one lethality occurred at 14 min during the exposure at $350^{\circ} \mathrm{C}$. The authors proposed that the postexposure deaths were caused by various hydrocarbons known to be generated from polyethylene decomposed in the temperature range of $350-500^{\circ} \mathrm{C}[52]$.

\section{SUMMARY}

In this report, a review has been made of the chemical nature and toxicity of the volatile products generated during combustion of polyethylenes. The thermal degradation products from polyethylenes are largely dependent upon the temperature and oxygen availability. In the absence of oxygen, a mixture of primarily n-alkanes and 1-alkenes are produced. In the presence of oxygen, additional oxygen-containing organic compounds (mostly low molecular weight aldehydes and carboxylic acids) are formed. Among the great number of gaseous products identified, $\mathrm{CO}$ appears to be the predominant toxicant. Non-flaming combustion also favored the production of acrolein and other irritant gases. Flaming combustion favored the production of $\mathrm{CO}_{2}$, hydrocarbons, and aromatics. Under restricted flaming with limited $\mathrm{O}_{2}$ content, production of $\mathrm{CO}$ increased with increasing temperature.

The toxicity of the combustion products from polyethylenes has been examined by seven different test procedures. Most of these test methods 
evaluated the toxicity by determining the numbers of animals affected and times to incapacitation and death without developing quantitative concentration-response relationships. In general, polyethylenes are more toxic in the non-flaming mode than in the flaming mode. The toxicity in the non-flaming mode increases with temperature and air supply. It is also greater when the material is decomposed with a high constant temperature than with a rising temperature program.

The HDPE $\mathrm{LC}_{50}$ values for 30 minute exposures (no post-exposure period) were about $25 \mathrm{mg} / \mathrm{l}$ in the non-flaming mode and about $50 \mathrm{mg} / \mathrm{l}$ in the flaming mode according to the Carnegie Mellon Institute of Research test method [51]. The $\mathrm{LC}_{50}$ values of the polyethylene foams calculated for 30 minute exposures and 14 day post-exposure periods was about $5 \mathrm{mg} / \ell$ in the non-flaming mode and about $35 \mathrm{mg} / \ell$ in the flaming mode according to results obtained by the Dow Chemical Company test method [26]. The $30 \mathrm{~min}$ and 14 day post-exposure $\mathrm{LC}_{50}$ value for polyethylene wire insulation in the non-flaming mode was greater than $75 \mathrm{mg} / \mathrm{l}$ when determined by the NBS toxicity test method [50]. Since acrolein is produced in the non-flaming mode and most deaths are postexposure, many studies have examined the production of acrolein. However, it is not clear whether the post-exposure deaths are due to acrolein alone or if additional irritant gases ought to be examined. The difference in the $\mathrm{LC}_{50}$ values in the non-flaming mode probably reflects the differences in the test methods and sample variability.

The only available comparative study of full-scale versus bench-scale experiments suggests that small-scale testing may produce toxicity results which overestimate those found under full-scale testing. Since numerous ful1- 
scale scenarios may be envisioned and only one has been studied, these findings may have only limited applicability.

The results presented in this review show that the toxicity of the combustion products from various samples of polyethylenes are not highly or unusually toxic.

\section{ACKNOWLEDGMENTS}

The authors gratefully acknowledge the help of Ms. N. Jason, Ms. M. Diephaus, Ms. A. Durham, and Ms. C.S. Bailey who performed the literature search and compiled the references. This study was supported in part by the Consumer Product Safety Commission. Dr. Rita Orzel was project officer under NBS contract no. 753-1386 (CPSC Task Order No. 84-8).

\section{REFERENCES}

1. Materials '84. A Modern Plastics Special Report. Modern Plastics $61: 45-67(1984)$.

2. Henkel, R.N., Polyethylene and ethylene copolymers. In "Modern Plastics Encyclopedia", J. Agranoff, ed., Volume 59, McGraw Hill, Inc., New York, 1982, pp. 73-98.

3. Cullis, C.F. and Hirschler, M.M., The Combustion of Organic Polymers. Clarendon Press, Oxford, England, 1981, pp. 320-345.

4. Madorsky, S.L., Thermal Degradation of Organic Polymers. Interscience Publishers, John Wiley \& Sons, Inc., New York, 1964, pp. 93-126.

5. Tsuchiya, Y. and Sumi, K., Thermal decomposition products of polyethylene. J. Poly. Sci. Part A-1 6-415-424 (1968).

6. Michal, J., Mitera, J., and Tardon, S., Toxicity of thermal degradation products of polyethylene and polypropylene. Fire and Matls. 1:160-168 (1976). 
7. Schwartz, R.J., Fire retardation of polyethylene and polypropylene. In "Flame Retardency of Polymeric Materials", W. Kuryla and A.J. Papa, eds., Volume 2, Dekker Pub1., New York, 1973, pp. 83-133.

8. Morimoto, T., Takeyama, K., and Konishi, F., Composition of gaseous combustion products of polymers. J. Appl. Sci. 20:1967-1976 (1976).

9. Pacakova, V., Nogatz, M., and Novak, V., Pyrolysis capillary gas chromatography of some polymeric materials. Collect. Czech. Chem. Commun. $47: 509-517(1982)$.

10. Hoff, A., Jacobsson, S., Pfaffli, P., Zitting, A., and Frostling, H., Degradation products of plastics. Scand. J. of Work, Environ. and Health 8: $1-60(1982)$.

11. Morikawa, T., Evolution of soot and polycyclic aromatic hydrocarbons from combustion and pyrolysis of polymers and low molecular weight hydrocarbons. Fire Sci. and Tech. 4 $4: 27-35$ (1984).

12. Michal, J., Determination of carbon monoxide in thermal degradation products of polymeric materials. Fire and Mat1s. $\underline{5}: 149-152$ (1981).

13. Morikawa, T., Effects of water vapor on evolution of carbon monoxide in combustion and pyrolysis. J. Comb. Tox. 9:85-96 (1982).

14. Michal, J., Combustion products of polymeric materials. I Test Chamber $\mathrm{CAB}$ 4.5. Fire and Matls. 7:163-166 (1983).

15. Michal, J., Combustion products of polymeric materials. II Test Chamber $\mathrm{CAB}$ 650. Fire and Mat1s. 7:169-172 (1983).

16. Paciorek, K.L., Kratzer, R.H., and Kaufman, J., Coal mine combustion products identification and analysis, Final Report No. BuMines-0FR-1-73 under Contract No. HO 122009 of Ultrasystems, Inc., Irvine, CA, July 1972,165 p.

17. Boettner, E.A., Ball, G.L., and Weiss, B., Combustion products from the incineration of plastics. Report 非PA-670/2-73-049 prepared under Grant 非P-00386 for the Office of Research and Development, U.S. Environmental Protection Agency, Washington, DC by the University of Michigan, Ann Arbor, Michigan, July 1973, 140 p.

18. Morikawa, T., Acrolein, formaldehyde, and volatile fatty acids from smoldering combustion. J. Comb. Tox. 3:135-150 (1976).

19. Hodgkin, J.H., Galbraith, M.N., and Chong, Y.K., Combustion products from burning polyethylene. J. Macromol. Sci. Chem. Al7:35-44 (1982).

20. Morikawa, T., Evolution of soot and polycylic aromatic hydrocarbons in combustion. J. Comb. Tox. 5:349-360 (1978). 
21. Zinn, B.T., Browner, R.F., Powe11, E.A., Joseph, K.T., Pasternak, M., Gardner, R.0., and Ndubizu, C., Investigations of smoke formation by polymeric materials: Smoke reduction methods and chemical characterization of particulates. Final Report on Nat. Bur. Stand. (U.S.) Grant No. G8-9003, for the period Oct. 1, 1978 to Sept. 30, 1979, $36 \mathrm{p}$.

22. Einhorn, I.N., Physiological and toxicological aspects of smoke produced during the combustion of polymeric materials. Environ. Health Perspect. $11: 163-189$ (1975).

23. Westerberg, L.M., Pfaffli, P., and Sundholm, F., Detection of free radicals during processing of polyethylene and polystyrene plastics. Am. Ind. Hyg. Assoc. J. 43:544-546 (1982).

24. Kuhn, R.L., Potts, W.J., and Waterman, T.E., A study of the inhalation toxicity of smoke produced upon pyrolysis and combustion of polyethylene foams. Part II: Full scale fire studies. J. Comb. Tox. 5:434-464 (1978).

25. Levin, B.C., Paabo, M., Bailey, C., Harris, S.E., and Gurman, J.L., Toxicological effects of the interactions of fire gases and their use in a toxic hazard assessment computer model. The Toxicologist 5:127 (1985).

26. Potts, W.J., Lederer, T.S., and Quast, J.F., A study of the inhalation toxicity of smoke produced upon pyrolysis and combustion of polyethylene foams. Part I: Laboratory studies. J. Comb. Tox. 5:408-433 (1978).

27. Kaplan, H.L., Grand, A.F., Rogers, W.R., Switzer, W.G., and Hartzel1, G.E., A research study of the assessment of escape impairment by irritant combustion gases in postcrash aircraft fires. Report \#DOT/FAA/CT-84/16 prepared under Grant \#DTFA 03-81-00065 for the Federal Aviation Administration, Atlantic City, NJ, by the Southwest Research Institute, San Antonio, TX, September 1984, 65 p.

28. Kaplan, H.L., Grand, A.F., and Hartzell, G.E., A critical review of the state-of-the-art of combustion toxicology. Final Report 01-6862, Southwest Research Institute, San Antonio, TX, June 1982.

29. Hofmann, H. Th. and Oettel, H., Comparative toxicity of thermal decomposition products. Modern Plast. 46:94-100 (1969).

30. Hofmann, H. Th. and Sand, H., Further investigations into the relative toxicity of decomposition products given from smoldering plastics. JFF/Comb. Tox. $1: 250-257$ (1974).

31. Standard Guide for Measurement of Gases Present or Generated During Fires. ASTM E 800-81, American Society for Testing Materials, Philadelphia, PA (1984).

32. Herpo1, C., Biological evaluation of the toxicity of products of pyrolysis and combustion of materials. Fire and Matls. 1:29-35 (1976). 
33. Herpol, C. and Minne, R., Biological evaluation of the toxicity of gases produced under fire conditions by synthetic materials. Part 2: Behavior of synthetic materials in definite combustion conditions as compared to the behavior of traditional materials in same conditions. Comb. Sci. and Tech. $12: 229-244$ (1976).

34. Herpol, C., Biological evaluation of toxicity caused by combustion of building materials. Fire and Matls. 4:127-143 (1980).

35. Herpol, C., Minne, R., and Van Outryve, E., Biological evaluation of the toxicity of gases produced under fire conditions by synthetic materials. Part 1: Methods and preliminary experiments concerning the reaction of animals to simple mixtures of air and carbon dioxide and carbon monoxide. Comb. Sci. and Technol. 12:217-228 (1976).

36. Herpol, C. and Vandevelde, P., Calculation of a toxicity index for materials based on a biological evaluation method. Fire and Mat 1s. 2:1-4 (1978).

37. Herpo1, C. and Vandevelde, P., Note on the non-existence of correlation between toxicity and other reaction to fire characteristics of materials. J. Comb. Tox. 2 : $135-142$ (1981).

38. Hilado, C.J. and Huttlinger, N.V., Toxicity of pyrolysis gases from some synthetic polymers. J. Comb. Tox. $\underline{5}: 361-369$ (1978).

39. Hilado, C.J., Soriano, J.A., and Kosola, K.L., Effect of heating rate on toxicity of pyrolysis gases from synthetic polymers. J. Comb. Tox. $\underline{4}: 533-555$ (1977).

40. Hilado, C.J. and Brauer, D.P., Polyethylene: effect of pyrolysis temperature and air flow on toxicity of pyrolysis gases. J. Comb. Tox. 6:63-67 (1979).

41. Hilado, C.J. and Smouse, K.Y., The effect of temperature and air flow on the relative toxicity of polymeric materials by the USF/NASA Toxicity Screening Test Method. J. Comb. Tox. 3:305-336 (1976).

42. Hilado, C.J. and Huttlinger, P.A., The use of rising temperature to integrate fixed temperature effects in off-gas toxicity. J. Comb. Tox. 7:201-206 (1980).

43. Hilado, C.J. and Cumming, H.J., Effect of carbon monoxide on Swiss albino mice. J. Comb. Tox. 4 :216-230 (1977).

44. Hilado, C.J., Carbon monoxide as the principal toxicant in the pyrolysis gases from materials. J. Comb. Tox. $\underline{6}: 177-184$ (1979).

45. Hilado, C.J. and Brauer, D.P., Concentration-time data in toxicity tests and resulting relationships. J. Comb. Tox. 6:136-149 (1979). 
46. Crane, R.C., Sanders, D.C., Endecott, B.R., Abbott, K.J., and

Smith, P.W., Inhalation toxicology: I Design of a small animal test system. II. Determination of the relative toxic hazards of 75 aircraft cabin materials. Prepared for Dept. of Trans., FAA, Washington, DC, Report No. FAA-AM-77-9, March 1977, 59 p.

47. Hilado, C.J., Cumming, H.J., Machado, A.M., Schneider, J.E., Crane, C.R., Sanders, D.C., Endecott, B.R., and Abbott, J.K., Comparison of animal responses to the combustion products generated by two test procedures, the USF/NASA methodology and the FAA/CAMI system. J. Comb. Tox. $\underline{4}: 325-359$ (1977).

48. Potts, W.J. and Lederer, T.S., A method for comparative testing of smoke toxicity. J. Comb. Tox. 4 :114-162 (1977).

49. Levin, B.C., Fowe11, A.J., Birky, M.M., Paabo, M., Stolte, A., and Malek, D., Further development of a test method for the assessment of the acute inhalation toxicity of combustion products. National Bureau of Standards, Gaithersburg, MD, NBSIR 82-2532 (June 1982).

50. Levin, B.C., unpublished data.

51. Gad, S.C. and Smith, A.C., Influence of heating rates on the toxicity of evolved combustion products: Results and a system for research. J. Fire Sci. 1 : 465-479 (1983).

52. Kishitani, K. and Nakamura, K., Study on toxicities of combustion products of building materials at initial stage of fire. Proceedings of the Second Joint Meeting, U.S. Japan Panel on Fire Research and Safety, UJNR, Tokyo, Oct. 19-22, 1976, 31 p.

53. Hilado, C.J. and Solis, A.N., Some possible reference materials for fire toxicity tests. J. Comb. Tox. 4 : 163-172 (1977).

54. Hilado, C.J. and Cumming, H.J., Studies with the USF/NASA toxicity screening test method: Carbon monoxide and carbon dioxide concentrations. J. Comb. Tox. 4:376-384 (1977).

55. Hilado, C.J. and Huttlinger, N.V., Concentration-response data on toxicity of pyrolysis gases from six synthetic polymers. J. Comb. Tox. 5:81-100 (1978).

56. Hilado, C.J., Olcomendy, E.M., and Schneider, J.E., Toxicity of pyrolysis gases from seat cushion materials. J. Cons. Prod. Flamm. 6:189-196 (1979).

57. Hilado, C.J., Cumming, H.J., and Schneider, J.E., Relative toxicity of pyrolysis gases from materials: Effects of temperature, air flow and criteria. Fire and Mat1s. 3:183-187 (1979).

58. Hilado, C.J., Cumming, H.J., and Casey, C.J., Relative flammability and toxicity of pyrolysis gases from cellular plastics. J. Cell. Plast. $15: 205-210$ (1979). 
59. H1lado, C.J., Huttlinger, P.A., and Shabdue, C.L., Smoke and toxic gases from materials in health care facilities. J. Cons. Prod. Flamm. 8:65-76 (1981). 
Table 1

Thermal Degradation Products Produced from Polyethylenes

Compound

Acetaldehyde

Acetic acid

Acetone

Acetylene

Acrolein

Acrylic acid

Anthracene

Benzene

Benzoanthracene

2,13-Benzofluoranthene

1,2-Benzof luorene

2,3-Benzof luorene

Benzo (a)pyrene

Benzo (c) pyrene

Butadiene

Butanal

Butane

Butene

1-Butene

2-Butene, cis

2-Butene, trans

Butyric acid

Butyrolactone

Caproic acid

Carbon dioxide

Carbon monoxide

Chrysene

Crotonic acid

Cyclohexane

Cyclohexene

Cyclopropane

Decanal

Decane

1-Decene

2,2-Dimethylbutane

2,2-Dimethy-cis-3-hexene

3,3-Dimethylheptane

2,4-Dimethylhexane

2,3-Dimethy 1-1-hexene

2,3-Dimethylpentane

Dodecanal

Dodecane
Atmosphere

0

0

0

$0, I$

0

0

0

$0, I$

0

0

0

0

$0, I$

0

$0, I$

0

$0, I, V$

$0, I$

$0, I, V$

$0, \mathrm{~V}$

$0, \mathrm{~V}$

0

0

0

$0, I$

$0, I$

0

0

$0, I$

0

0

0

$0, I$

$0, I$

I

I

I

I

I

I

0

$0, I$

\section{Reference}

10,19

$10,18,19$

10,19

8

$10,18,19,24,26$

6,10

20,21

$6,8,9,10,16$

20,21

21

21

21

11,20

20

6,7

6,10

$4,5,6,7,10,17$

$4,6,10$

$5,7,9,10,17$

5,17

5,17

10

10

10

$6,8,9,10,14,15,17$, $24,26,30,32,33,34$, $47,53,54,55$ $8,9,13,14,15,17,24$, $26,30,32,33,34,39,40$, $44,45,47,51,52,53$, $54,55,56,57,58$

21

10

6,9

6

10

6

6,7

$6,7,10$

9

9

10

9,10

9

9

6

6 
Table 1 (continued)

\section{Compound}

1-Dodecene

Epoxide

Ethane

Ethanol

Ethyl benzene

Ethyl cyclopentene

Ethylene

2-Ethy 1-1-hexene

Fluoranthene

Formaldehyde

Formic acid

Furan

Heptadecane

1 -Heptadecene

1,3-Heptadiene

1,6-Heptadiene

Heptanal

Heptane

2-Heptanone

Heptene

1 -Heptene

Hexadecane

1 -Hexadecene

Hexadiene

1,3-Hexadiene

1,5-Hexadiene

Hexana 1

Hexane

2-Hexanone

Hexene

1 -Hexene

2-Hexene

3-Hexene

Hydrogen chloride

Hydroperoxide

Hydroxyvaleric acid

Isobutene

Isobutanal

Isobutylene

Isodecane

Isononane

Isooctane

Isovaleric acid

Methane

Methanol
Atmosphere

$\underline{\text { Reference }}$

$\begin{array}{cc}0, I & 6,10 \\ 0 & 6\end{array}$

$0, I, V$

0

$0, I$

$I$

$0, I, V$

I

0

0

0

0

I

$0, I$

I

I

0

$0, I$

0

$0, I$

$0, I$

$0, I$

$0, I$

I

I

I

0

$0, I, V$

0

$0, I$

$0, I, V$

0

I

0

0

0

I

0

V

I

I

I

0

$0, I, V$

0
$4,5,7,9,10,16,17$, $19,47,53,55$

10

6

$4,5,7,8,9,10,16,17$

$19,47,53,55$

10

20,21

10,18

10,18

10

6

6

9

9

6

$4,6,7,9,10$

10

4,20

$6,7,9,10$

6

6

4

9

9

6

$4,5,6,7,9,10$

10

4,10

$5,6,7,9,10,17$

17

9

16

10

10

7

10

5

7

7

7

10

$5,7,8,9,16,17,39$, $40,44,45,47,53,55$ 56,58

10 
Table 1 (continued)

Compound

2-Methylbutane

2-Methyl-1-butene

3-Methyl-1-butene

Methylcyclohexane

Methylcyclohexene

Methylcyclopentene

4,5-Methylene phenanthrene

2-Methyl-4-ethylhexane

Methyl ethyl ketone

2-Methyl-3-ethylpentane

2-Methyl-3-ethy 1-2-pentene

2-Methylheptane

2-Methyl-1-heptene

2-Methy1-3-heptene

3-Methyl-1-heptene

2-Methyl-1-hexene

3-Methyl-1-hexene

4-Methyl-2-hexene

Methyl-4,5-methylene phenanthrene

2-Methylpentane

2-Methyl-1-pentene

2-Methyl-2-pentene

4-Methyl-1-pentene

Methyl-phenanthrene

2-Methylpropane

2-Methyl-2-propenal

2-Methylpropene

Methylpyrene

Methyl vinyl ketone

1,3-Nonadiene

Nonana 1

Nonane

1 -Nonene

Octadecane

1 -Octadecene

1,3-Octadiene

Octanal

Octane

Octene

1-Octene

Pentadecanal

Pentadecane

1-Pentadecene

Pentadiene

1,3-Pentadiene

1,4-Pentadiene

Pentanal

Pentane

2-Pentanone

Pentene
Atmosphere

$\mathrm{V}$

I, V

I,

I

0

0

I

0

I

I

I

I

I

I

I

I

I

0

V

V

I

I, V

0

V

0

v

0

0

I

0

$0, I$

$0, I$

I

$0, I$

0

0

$0, I$

0

$0, I$

0

$0, I$

$0, I$

I

I, V

I, V

0

$0, I, V$

0

$0, I$
Reference

5

5

5,9

9

10

6

21

10

10,19

9

9

9

9

9

10

9

9

9

21

5

5

9

5,9

21

5

10

5

21

10

9

6

$6,7,9,10$

$6,7,9,10$

6

6

9

6

$6,7,9,10$

20

$6,7,9,10$

6

6

6

4

5,9

5,9

6,10

$4,5,6,7,9,10,17$

10

$4,6,9$ 
Table 1 (continued)

\section{Compound}

1 - Pentene

2-Pentene

Phenanthrene

Propadiene

Propane

Propanol

Propionaldehyde

Propionic acid

Propylene

Pyrene

Tetradecanal

Tetradecane

1 -Tetradecene

Tetrahydrofuran

Toluene

Tridecanal

Tridecane

1 -Tridecene

2,3,3-Trimethy1-1-butene

2,2,3-Trimethy1-1-pentane

Trimethylcyclopentane

2,2,5-Trimethylhexane

2,3,4-Trimethylpentane

Triphenylene

Undecanal

Undecane

1 -Undecene

Valerolactone

Water

0 : oxidative atmosphere

I: inert atmosphere

$\mathrm{V}$ : vacuum

\section{Atmosphere}

$0, I, V$

$\mathrm{V}$

0

I

$0, I, V$

0

$0, I$

0

$0, I, V$

0

0

$0, I$

$0, I$

0

$0, I$

0

$0, I$

$0, I$

I

I

I

I

I

0

0

$0, I$

$0, I$

0

0
Reference

$5,7,10,17$

5

22

4

$4,5,7,9,10,17,19$

10

$6,10,14,19$

10,18

$4,5,6,7,9,10,16,17,19$

20,21

6

6

6

10

6,19

6

6

6

9

9

10

9

9

21

6

6

6,10

10

9,10 
Table 2

Degradation Products Generated from a Polyethylene During Pyrolysis, Thermooxidation, and Combustion [6]

Product

Carbon dioxide

Propylene

Butylene

Butane

1,3 Butadiene

Pentene + Propana1

$\mathrm{n}$-Pentane

Butyraldehyde

Cyclohexane

Hexene-1

$\mathrm{n}$-Hexane

Cyclohexene

Benzene

Methylcyclopentene

Valeraldehyde

Heptene-1

n-Heptane

Toluene

Ethylcyclopentene

Methyl isobutyl ketone

(or allyl acetate)

Hexana 1

Octen-1

n-Octane

Acrylic acid

Ethyl benzene

Heptanal

Nonene-1

n-Nonane

Epoxide

Keto-aldehyde

Octanal

Decene-1

n-Decane

Undecene-1

n-Undecane

Nonanal

Decanal

Tridecene-1

n-Tridecane

Undecana 1

Silicone

Tetradecene-1
Thermo-

\begin{tabular}{ccc}
$\begin{array}{c}\text { Pyrolysis } \\
(\%)^{\mathrm{a}}\end{array}$ & $\begin{array}{c}\text { oxidation } \\
(\%)\end{array}$ & $\begin{array}{c}\text { Combustion } \\
(\%)\end{array}$ \\
\hline
\end{tabular}

0.1

0.1

1.5

1.5

0.75

6.5

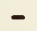

-

-

9.9

4.8

$-$

2.6

$-$

5.6

6.2

0.8

0.5

5.7

4.6

$-$

1.3

$-$

5.4

3.5

$-$

-

$-$

5.8

3.0

4.3

3.0

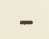

$-$

1.9

1.5

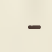

$-$

2.0
0.4

0.35

3.7

$-$

4.1

7.5

7.4

6.2

14.5

4.5

$-$

$-$

0.27

0.65

2.5

11.5

1.4

1.3

0.9

2. 2

5.6

$-$

0.9

0.89

3.1

0.7

1.4

0.3

0.6

2.5

$-$

0.6

-

$-$

1.9

0.8

$-$

-

0.4

0.1

-
2.7

3.9

2.0

0.8

2.5

3.1

2.7

1.2

0.2

0.3

0.2

0.7

0.3

\section{N}

. 3

1.1

6.7

3.9

5.8

3.3

4.9

2.2

5.9

0.8

5.6

3.0

1.6

3.3

1.7

\section{7}

9
0

8

1

7

2

0.2

0.9

0.3

$-$

-

0.2

0.4

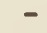

$-$

0.15 
Table 2 (continued)

Product

n-Tetradecane

Dodecanal

Pentadecene-1

n-Pentadecane

Tridecanal

Hexadecene-1

n-Hexadecane

Tetradecanal

Heptadecene-1

$+\mathrm{n}$-Heptadecane

Pentadecanal

Octadecene-1

+ n-Octadecane
Thermooxidation

(\%)

Combustion

(\%)

Pyrolysis
$(\%)^{a}$

1.2

- 0.2

1.8

0.7

1.3

$-$

-

0.1

0.9

$-$

0.5

0.4

$-$

0.

0.1

$-$

$-$

0.1

0.6

0.5
0.2

0.15

0.15

$-$

0.07

0.07

$-$

0.15

$-$

0.15

Pyrolysis: thermal degradation in inert atmospheres Thermooxidation: thermal degradation in oxidative atmosphere Combustion: flaming degradation

a: volume percent calculated from the total chromatogram area. $\mathrm{N}$ : not determined 
Table 3

$\mathrm{CO}$ and $\mathrm{CO}_{2}$ Concentrations in the Combustion Products from a Polyethylene [14]

$\begin{array}{ccccc}\begin{array}{c}\text { Combustion } \\ \text { mode }\end{array} & \begin{array}{c}\text { Temp. } \\ \left({ }^{\circ} \mathrm{C}\right)\end{array} & \begin{array}{c}\text { Sample } \\ \text { weight } \\ (\mathrm{mg})\end{array} & \begin{array}{c}\mathrm{CO} \\ (\%)\end{array} & \begin{array}{c}\mathrm{CO}_{2} \\ (\%)\end{array} \\ & 500 & 100 & 0.238 & 1.24 \\ & 200 & 0.472 & 1.95 \\ \mathrm{~F} & 300 & 0.738 & 2.71 \\ & 600 & 100 & 0.126 & 2.60 \\ & 200 & 0.297 & 3.72 \\ & 300 & 0.513 & 3.66\end{array}$

a: Volume $\%$ as measured in the animal test chamber NF: Non-flaming

F: Flaming 


\section{Table 4}

Concentrations of Polycyclic Aromatic Hydrocarbons in Smoke Particulates from a Polyethylene [21]

\section{PAH Species}

Phenanthrene, Anthracene

4,5-Methylene Phenanthrene

Methy1-Phenathrene

Fluoranthene

Pyrene

Methy1-4,5-Methylene Phenanthrene

1,2-Benzofluorene

2,3-Benzofluorene

Methyl-Pyrene

2,13-Benzofluoranthene

Chrysene, Benzoanthracene, Triphenylene

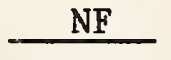

$48.16^{a}$

12.47

2.45

0.64

18.98

51.84

46.38

0.61

1.77

1.33

1.14

5.64

8.59

\footnotetext{
a: mole \%

PAH: Polynuclear aromatic hydrocarbon

NF: Non-flaming

F: Flaming
} 
Table 5

Toxicological Effects on Rats Exposed to the Pyrolysis Products

from a Polyethylene a Decomposed by the DIN Method [29]

\begin{tabular}{ccc}
$\begin{array}{c}\text { Temperature } \\
\left({ }^{\circ} \mathrm{C}\right)\end{array}$ & $\begin{array}{l}\text { COHb } \\
(\%)\end{array}$ & $\frac{1}{\text { Number of deaths }}$ \\
\hline 200 & $<15$ & $0 / 12$ \\
300 & $<15$ & $0 / 12$ \\
400 & 79 & $12 / 12$ \\
500 & 85 & $12 / 12$ \\
600 & 82 & $12 / 12$
\end{tabular}

a sample weight $=5$ grams 
Table 6

Toxicological Effects on Rats Exposed to Combustion Products from Polyethylenes ${ }^{a}$ Decomposed According to the DIN Toxicity Test Method [32-34]

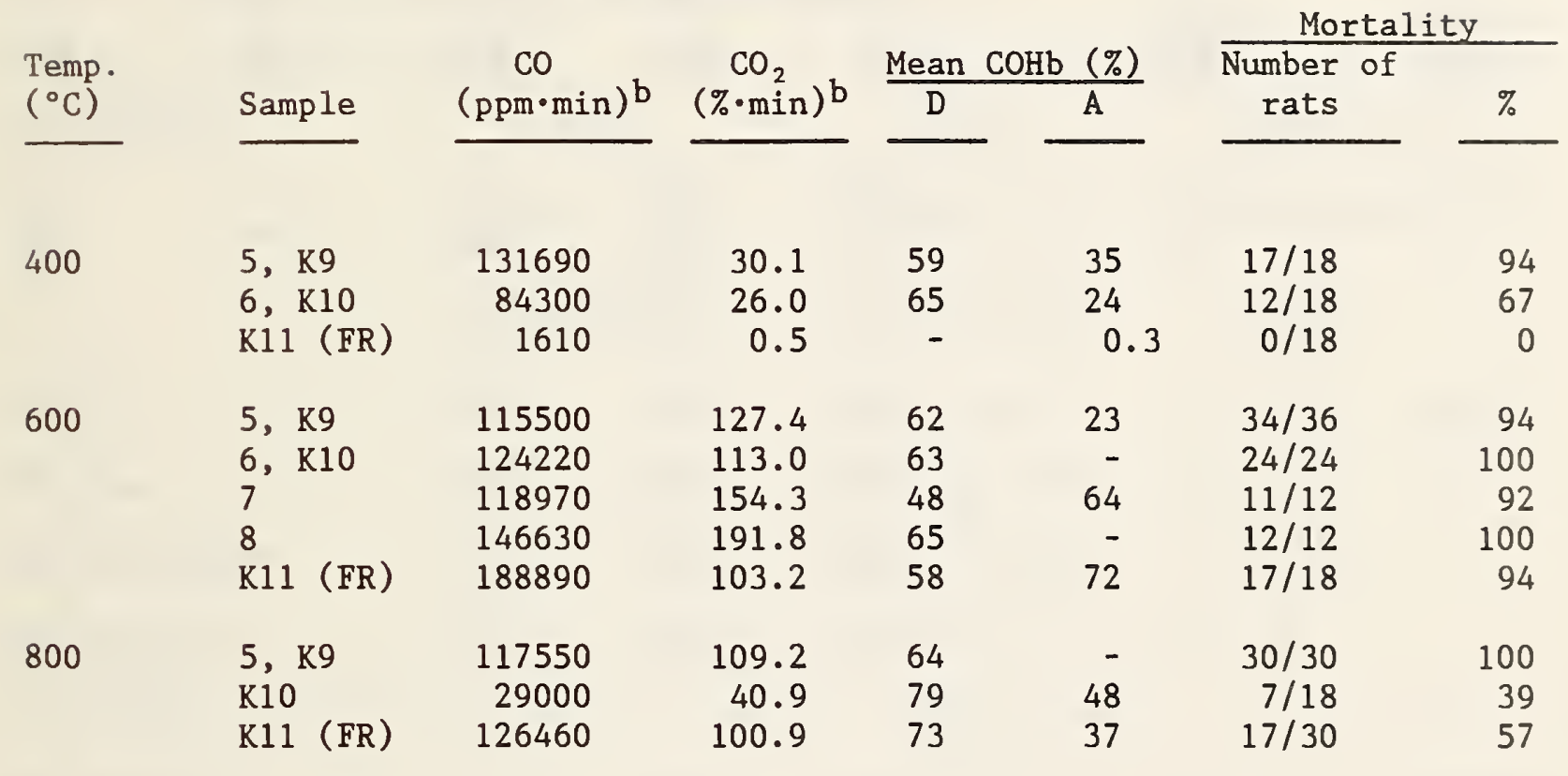

\footnotetext{
a: $10 \mathrm{~g}$ samples

b: Accumulated concentration for 30 minutes

D: Dead animals

A: Alive animals
} 
Table 7

Variation of Mean Respiration Frequency ${ }^{2}$ in Rats Exposed to Polyethylenes Decomposition Products $[32,33]$

\begin{tabular}{|c|c|c|c|c|c|c|}
\hline \multirow{3}{*}{$\begin{array}{l}\text { Temp. } \\
\left({ }^{\circ} \mathrm{C}\right) \\
\end{array}$} & \multirow{3}{*}{$\begin{array}{c}\text { Sample } \\
\text { No. } \\
\end{array}$} & \multicolumn{5}{|c|}{ Mean respiratory frequency at: } \\
\hline & & 6 & 12 & 18 & 24 & 30 \\
\hline & & $\underline{\min }$ & $\underline{\min }$ & $\underline{\min }$ & $\underline{\min }$ & $\underline{\min }$ \\
\hline \multirow[t]{2}{*}{400} & 5 & 89 & 73 & 34 & 28 & 9 \\
\hline & 6 & 97 & 96 & 100 & 53 & 26 \\
\hline \multirow[t]{2}{*}{600} & 5 & 76 & 46 & 28 & 9 & 4 \\
\hline & 6 & 82 & 43 & 20 & 8 & 0 \\
\hline & 7 & 63 & 31 & 53 & 33 & 8 \\
\hline & 8 & 55 & 36 & 13 & 0 & 0 \\
\hline 800 & 5 & 37 & 14 & 4 & 1 & 0 \\
\hline
\end{tabular}

a expressed as percent of the mean normal value before the test. 
Toxicity Results for Polyethylenes ${ }^{a}$ Decomposed According to the University of San Francisco Method Using the Rising Temperature Mode ${ }^{b}$

Sample

Designation

PE1

PE2

PE foam

PE foam

PE microfoam

PE solid 1

PE solid 2

PE solid 3

PE solid 5 (LDPE)

PE solid 6 (HDPE)

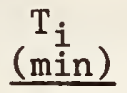

$15.52 \pm 4.44^{c}$

$11.54 \pm 0.62$

$11.74 \pm 0.29$
$\mathrm{T}_{\mathrm{d}}$

(min)

$22.60 \pm 0.45$

$13.99 \pm 0.85$

$19.84 \pm 0.29$

$20.68 \pm 0.36$

$20.93 \pm 0.47$

$20.42 \pm 0.26$

19.84

22.66

24.69

$18.60 \pm 0.30$

$18.29 \pm 1.22$
Reference

$47,53,54,55$

41 $53,54,55$

56,58

58,59

58,59

44

44

44

38,44

38,44

a: sample weight 1 gram

b: $40^{\circ} \mathrm{C} / \mathrm{min}$ from 200 to $800^{\circ} \mathrm{C}$

c: standard deviation of average times from 2 or more experiments

$\mathrm{T}_{i}$ : average time to staggering

$\mathrm{T}_{\mathrm{d}}$ : average time to death

$\mathrm{PE}$ : Polyethylene 
Table 9

Survival Times of Test Animals Exposed to Smoke from a Polyethylene ${ }^{a}$ Decomposed Under Different University of

San Francisco Test Method Conditions [42]

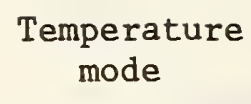

Fixed

400
500
600
700
800

Rising

200 to $800^{\circ} \mathrm{C}$ at $40^{\circ} \mathrm{C} / \mathrm{min}$

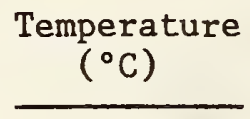

300

800
Mean Time-to-death (min)

No air flow Air flow

31.0

$30^{c}$

29.3

7.0

21.5

6.8

15.8

8.2

13.8

$30^{c}$

11.7

$30^{c}$

22.7

13.8

a: sample designation P1

b: air flow rate $1 \mathrm{l} / \mathrm{min}$

c: when no deaths occurred during the 30 minute exposure, a survival time of 30 minutes is indicated 
Gas Analyses of the Combustion Products from Polyethylenesa Examined via the University of San Francisco Test Method ${ }^{b}$

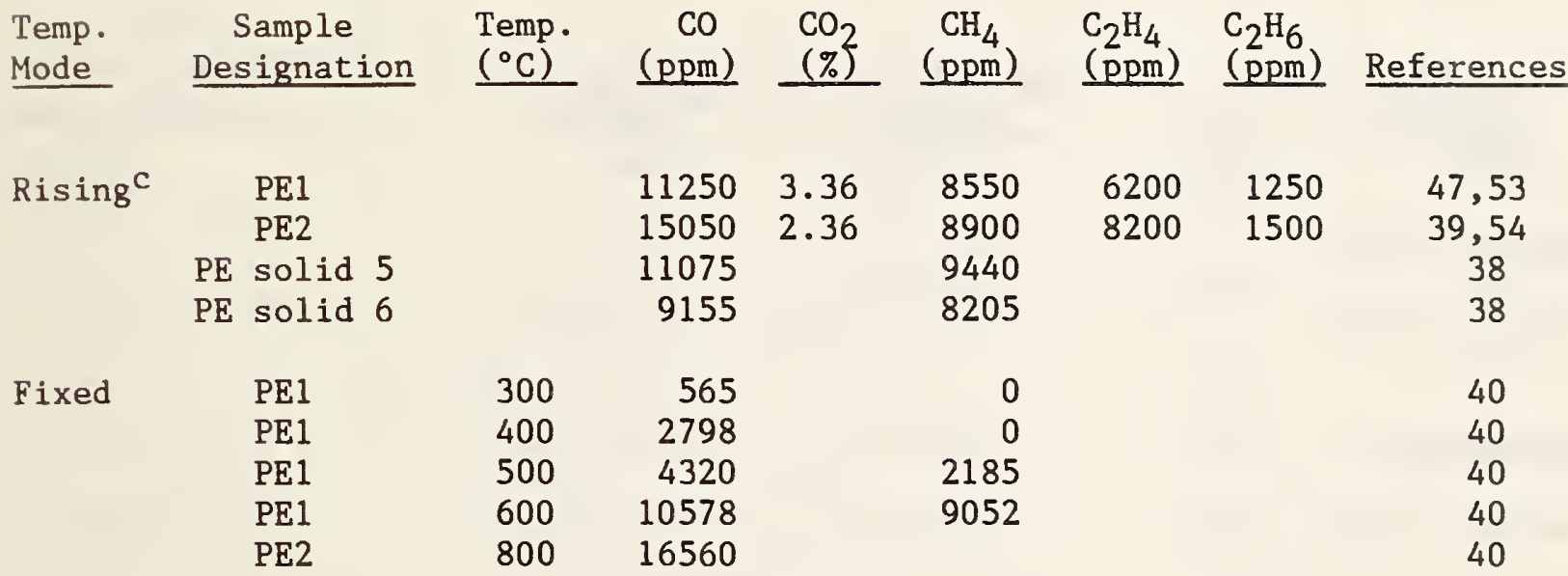
a: sample weight $1 \mathrm{gram}$
b: without forced air flow
c: $40^{\circ} \mathrm{C} / \mathrm{min}$ from 200 to $800^{\circ} \mathrm{C}$ 
LC $_{50}$ Values Calculated for Different Polyethylene Foams Decomposed by the Dow Chemical Company Test Procedure [26]

Sample

ETHAFOAM 220

XFS4101 (FR)

ETHAFOAM220

XFS4101 (FR)
Combustion

mode

F

F

NF

NF
$\mathrm{LC}_{50}$

(mg9l)

$\sim 35$

31.3

5.3

$\sim 6.1$
$95 \%$

Confidence limits $(\mathrm{mg} / \mathrm{\ell})$

$34-41$

$29.3-33.3$

$4.4-6.6$

$5.3-6.9$

F: flaming

NF : non-flaming 
Table 12

\section{Influence of Heating Rates on the Toxicity of Combustion Products from a Polyethylene [51]}

Heating

rate a $^{\text {a }}$

20

30

40

50

\begin{tabular}{lc}
$\frac{2}{2}$ Polyethylene \\
\hline $\mathrm{LC}_{50} \mathrm{~b}$ & $\mathrm{IC}_{50} \mathrm{~b}$ \\
$(\mathrm{mg} / \mathrm{l})$ & $(\mathrm{mg} / \mathrm{l})$ \\
\hline
\end{tabular}

25.2

24.7

$48.4 *$

$51.2 *$

10.6

9.6

$<12.4^{*}$

$<19.6 *$
Douglas Fir

\begin{tabular}{lc}
\hline $\mathrm{LC}_{50}$ & $\mathrm{IC}_{50}$ \\
$(\mathrm{mg} / \mathrm{l})$ & $(\mathrm{mg} / \mathrm{l})$ \\
\hline
\end{tabular}

43.0

33.5

38.5

19.9

39.3

19.6

21.5

14.8

\footnotetext{
a: ${ }^{\circ} \mathrm{C}$ per minute from $25^{\circ} \mathrm{C}$

b: value calculated on basis of material volatilized during the 30 minute exposures

*: flaming experiments
} 



\begin{tabular}{|c|c|c|c|}
\hline U.S. DEPT. OF COMM. & $\begin{array}{l}\text { 1. PUBLICATION OR } \\
\text { REPORT NO. }\end{array}$ & 2. Performing Organ. Report No. & 3. Publication Date \\
\hline $\begin{array}{l}\text { BIBLIOGRAPHIC OATA } \\
\text { SHEET (See instructions) }\end{array}$ & NBSIR $-85 / 3268$ & & January 1986 \\
\hline
\end{tabular}

4. TITLE AND SUBTITLE

\section{A LITERATURE REVIEW OF THE CHEMICAL NATURE AND TOXICITY OF THE DECOMPOSITION PRODUCTS OF POLYETHYLENES}

5. AUTHOR(S)

Maya Paabo and Barbara C. Levin

\begin{tabular}{l|l|}
\hline 6. PERFORMING ORGANIZATION (If joint or other thon NBS, see instructions) & 7. Contract Grant No. \\
MATIONAL BUREAU OF STANDAROS & \\
DEPARTMENT OF COMMERCE & \\
GaIthersburg, MD 20899 & 8. Type of Report \& Period Covered
\end{tabular}

9. SPONSORING ORGANIZATION NAME AND COMPLETE ADDRESS (Street, City, State, ZIP)

The U. S. Consumer Products Safety Commission

Bethesda, MD 20207

10. SUPPLEMENTARY NOTES

[Document describes a computer program; SF-185, FIPS Software Summary, is attached.

11. ABSTRACT (A 200-word or less foctual summary of most significant information. If document includes a significant bibliography or literature survey, mention it here)

The literature on polyethylenes has been reviewed with an emphasis on the identification of gaseous products generated under various thermal decomposition conditions and the toxicity of those products. This review is limited to publications in English through 1984. The analytical chemical studies of the thermal decomposition products generated under vacuum, inert and oxidative experimental conditions are described. In oxidative atmospheres, which most closely simulate real fire conditions, carbon monoxide (CO) was found to be the predominant toxicant. Acrolein was another toxicant often noted in these reviewed studies. More acrolein was generated under non-flaming than under flaming conditions.

Results from seven different test procedures were considered in assessing the acute inhalation toxicity of combustion products from various polyethylene formulation. The combustion products generated from the polyethylenes studied in the non-flaming mode appeared to be slightly more toxic than those produced in the flaming mode. In the non-flaming mode, the $\mathrm{LC}_{50}$ values ranged from 5 to $75 \mathrm{mg} / \mathrm{l}$. In the flaming mode, the $\mathrm{LC}_{50}$ values ranged from 31 to $51 \mathrm{mg} / \mathrm{l}$. The toxicity of the degradation products of polyethylenes appears to be similar to that found for other common materials designed for the same end uses.

12. KEY WORDS (Six to twelve entries; alphabetical order; capitalize only proper names; and separate key words by semicolons) Comuustion products, Iicerature reviews, polyethylenes, thermal decomposition, toxicity.

13. AVAILABILITY

$\mathrm{x}$ Unlimited

For Official Distribution. Do Not Release to NTIS

Order From Superintendent of Documents, U.S. Government Printing Office, Washington, D.C. 20402.

[x] Order From National Technical Information Service (NTIS), Springfield, VA. 22161
14. NO. OF PRINTED PAGES 68

15. Price 


